\title{
Measurement and modelling of rainfall partitioning by deciduous Potentilla fruticosa shrub on the Qinghai-Tibet Plateau, China
}

Si-Yi Zhang a, b, Xiao-Yan Li ${ }^{\text {b, c }}$

${ }^{a}$ Guangdong Key Laboratory of Agricultural Environment Pollution Integrated Control, Guangdong

5 Institute of Eco-Environmental Science \& Technology, Guangzhou 510650, China

${ }^{\mathrm{b}}$ State Key Laboratory of Earth Surface Processes and Resource Ecology, Beijing Normal University, Beijing, 100875, China

${ }^{\mathrm{c}}$ College of Resources Science and Technology, Beijing Normal University, Beijing, 100875, China Correspondence to: Si-Yi Zhang (dxzqyzsy@,163.com)

10 Abstract. Rainfall partitioning is a key process of ecosystem water cycle which has not get enough attention in the alpine deciduous shrub. Moreover, there is no apposite analytical model that suits to estimate the rainfall redistribution of the deciduous shrub with great changes in coverage and leaf storage capacity due to foliation and defoliation. Field and laboratory experiments to assess these processes and to determine vegetation and

15 atmospheric parameters were established for deciduous Potentilla fruticosa shrub on the Qinghai-Tibet Plateau. Based on the experimental data, a variable parameter Gash model especially for deciduous shrub rainfall partitioning which is adapted from the revised Gash model was developed to represent these processes. The performance of the variable parameters Gash model in modeling the rainfall partitioning of the deciduous shrub 20 patches is better than that of the original model. The variable parameters Gash model 
treated the water captured by the stem as that captured by leaf canopy considering the low height of shrub and its low coverage in leafless period. Thus, the model developed here were perfect to represent the rainfall partitioning processes. It was found that the interception, throughfall and stemflow accounted for $21.44 \%, 29.26 \%$ and $49.30 \%$ of gross

5 rainfall in the shrub patches during the growing season of 2012, respectively. $42.6 \%$ of the interception was loss by evaporation from the saturated leaf canopy during rainfall events. The results indicate that adaptations of the analytical model in this paper improved its performance and provide hypotheses more near the realities in the deciduous shrub.

\section{Introduction}

10 Rainfall partitioning by vegetation is a key process of ecosystem water cycle. The gross precipitation reaches the canopy is redistributed to interception, stemflow and free throughfall (Crockford and Richardson, 2000). These processes have important effect on runoff, soil moisture, geochemical cycle, erosion, and so on (Levia and Frost, 2003; Bryant et al., 2005; Llorens and Domingo, 2007; Li et al., 2009). A lot attention has been paid to

15 the rainfall partitioning by different types of plant, forest, shrub, grass and crop in all over the world. Shrub is a common top biological community in arid or semiarid region. Former researches have reported that vegetation in arid or semiarid region has high efficient redistribution of rainfall to adapt to the water limited habitats (Carlyle-Moses, 2004; Owens et al., 2006; Johnson and Lehmann, 2009; Garcia-Estringana et al., 2010; Li, 2011). 
Hydrol. Earth Syst. Sci. Discuss., doi:10.5194/hess-2016-589, 2016

Manuscript under review for journal Hydrol. Earth Syst. Sci.

Published: 8 December 2016

(c) Author(s) 2016. CC-BY 3.0 License.

(c) (1)
Hydrology and

Earth System

Sciences

Discussions

Interception, stemflow and throughfall accounts for $3.0-47.6 \%, 2.0-43.3 \%$ and $31.5-83.3 \%$ of the gross precipitation, respectively (Table 1). The interception of canopy evaporates to the atmosphere directly, and this flux is an important composition of ecosystem evapotranspiration and energy fluxes and has great effect on the water and energy balance at local and catchment scale (Llorens and Domingo, 2007; Zhang, 2014). The stemflow funnels part of rainfall to the ground around the plant trunks or stems, this flux usually is small, accounting for $11.9 \%$ of gross precipitation (Table 1), but has important effect on runoff generation, spatial patterning of soil moisture, water erosion, groundwater recharge, geobiochemical circulation and understory ecosystem components (Levia and Frost, 2003).

10 A lot of models have been developed to estimate rainfall partitioning by vegetation for better understanding their process and composition. (Muzylo et al., 2009). Regression model were easy got but unsuitable to adapt to other species or location with different canopy structure and weather condition. Analytical models established by Rutter (Rutter et al., 1971; 1975), Gash (Gash, 1979; Gash et al., 1995) and Liu (Liu, 1998) were mostly

15 used in rainfall partitioning researches. These models estimate interception, stemflow and throughfall using a series of parameters containing canopy structures and weather characteristics. These parameters can be got from direct measurement or indirect regression. The models always base on some hypothesis of the conditions and process of wet canopy evaporation, stemflow generation and so on. Mostly, these models commonly 20 were applied in forests, whereas, application in shrub or grass ecosystems are relatively 
Hydrol. Earth Syst. Sci. Discuss., doi:10.5194/hess-2016-589, 2016

Manuscript under review for journal Hydrol. Earth Syst. Sci.

Published: 8 December 2016

(c) Author(s) 2016. CC-BY 3.0 License.

(c) (1)
Hydrology and

Earth System

Sciences

Discussions

rare (Muzylo et al., 2009), partly due to the difficulty of water flow measurement techniques (Dunkerley, 2000). The canopy structures of shrub are obvious different from those of forest. Some canopy structure parameters of shrub can be much easier to be directly measured than those of trees because that the shrub is smaller than tall trees.

In most forest researches, the parameters of canopy structure and some weather condition in analytical models are set as constants or semi-constants (Muzylo et al., 2009), such as Su et al. (2016a). However, the canopy structure often changes seasonally. Especially, the deciduous vegetation canopy changes greatly from leafless to leafed season. Some researchers have change the canopy parameters seasonally (Muzylo et al., 2012) or 10 monthly (Deguchi et al., 2006). However, studies focused on rainfall partitioning of changing vegetation canopy are relatively rare, and more studies are required to better represent the components and process of rainfall partitioning influenced by changing vegetation canopy (Muzylo et al., 2009; Carlyle-Moses and Gash, 2011). Changing parameters in model according to their changes over time could improve the estimated 15 results of rainfall partitioning.

This study aims to measure the rainfall partitioning of deciduous Potentilla fruticosa shrub on the Qinghai-Tibet Plateau, and to model their rainfall partitioning using adapted analytical model. The adapted model will consider the special canopy structure of deciduous shrubs. Some hypotheses would be reset due to the special canopy structure and 20 weather condition. The changes of canopy parameter relating to the process of foliation 
and defoliation were monitored and some important canopy parameter measured directly. The results using adapted model were compared with those of the original model. The specific objectives of this study were (1) to measure and analyze the rainfall interception, stemflow and throughfall of P. fruticosa shrub on the Qinghai-Tibet Plateau, China, and (2) to adapt the revised Gash model to the deciduous shrub using the directly measured variable parameters and to compare the results.

\section{Materials and methods}

\subsection{Study site}

The study was conducted at the north of Qinghai Lake watershed, on the northeast of 10 the Qinghai-Tibet Plateau, China $\left(37.594^{\circ} \mathrm{N}, 100.006^{\circ} \mathrm{E}, 3353 \mathrm{~m}\right.$ above sea leaf). The site belongs to an alpine cold semiarid region. The mean annual temperature recorded at a National Weather Station $33 \mathrm{~km}$ downstream of the experimental site is $0.1{ }^{\circ} \mathrm{C}$ and temperature in January is -14.3 to $-9.8{ }^{\circ} \mathrm{C}$, and in July is 10.9 to $15.6{ }^{\circ} \mathrm{C}$. The mean annual precipitation is $389.4 \mathrm{~mm}$, and $85 \%$ precipitation happens from May to September.

15 The pan evaporation is 1300 to $2000 \mathrm{~mm}$. The dominant species is $P$. fruticosa shrub. It grows as patches with multiple stems connecting with underground stems. The coverage of shrub is $26 \%$, and the height of shrub is $35.4 \mathrm{~cm}$. The mean area of a $P$. fruticosa patch is $0.23 \mathrm{~m}^{2}$. Other accompanying herb species are Kobresia pygmaea, Carex moorcroftii, Potentilla saundersiana and Polygonum viviparum. Due to the high elevation and cold 
weather, the grow season is short and begins at late May and ends at early October. In this study, only the rainfall partitioning in the P. fruticosa shrub patches was considered, that in the inter-patch was not considered.

\subsection{Measurements of rainfall partitioning and model parameters}

During the period 1 June 2012 and 11 September 2012, the rainfall partitioning at the P. fruticosa patches were measured. The gross precipitation was measured by a tipping rainfall gauge (ARG100, Campbell, USA). The rainfall events were discretized by assuming without rainfall between events of $12 \mathrm{~h}$, so that there is enough time for the canopy to dry out. $12 \mathrm{~h}$ not $8 \mathrm{~h}$ (the Gash model recommended, Gash, 1979) was chosen

10 here because the evaporation rate in the alpine ecosystem is relative lower than other ecosystem in low altitude (Zhang, 2014). The stemflow was measured following the method of Zhang et al. (2015a). A small sink was established by wrapping a piece of aluminium foil at the base of stem, the collected stemflow in the sink was drained to a storage bottle through a flexible plastic tube. Because it is very difficult to collect stemflow

15 in the remote area, we did not measure stemflow for each rainfall events, and we measured and recorded stemflow eight times during the study period, i.e., 11, 20 and 29 June, 17 and 31 July, 22 August and 2 and 11 September, respectively. Totally, 6 stems were selected to measure stemflow. The diameters of the 6 stems ranged from 3.42 to $7.52 \mathrm{~mm}$. The aboveground biomass of the 6 stems was collected when the experiment ended and was 
oven-dried at $65^{\circ} \mathrm{C}$ and then weighed. A regression equation for the relationship between the stem canopy structure and rainfall characteristic was obtained using stepwise regression method following Zhang et al. (2015a). The equation was formed as:

$$
S F_{v}=a * q+b * P_{G}+c * P_{G} * M_{d}
$$

5 where $S F_{v}$ is the volume of stemflow $(\mathrm{ml})$ collected from a branch in a special period; $q$ is the number of rainfall events that generate stemflow; $P_{G}$ is gross precipitation $(\mathrm{mm}) ; M_{d}$ is the dry aboveground biomass of the branch $(\mathrm{g}) ; a, b$ and $c$ are the regression coefficients. The aboveground biomass of $P$. fruticosa patches was collected and oven-dried at the same time. The patch stemflow at each rainfall event was calculated using Eq. (1) with rainfall

10 depth and patch aboveground biomass.

The throughfall was measured using 9 collecting bottles. The throughfall collecting bottles are $3.34 \mathrm{~cm}$ in diameter and $15 \mathrm{~cm}$ in height with a funnel at the top. The bottles were placed under 3 P. fruticosa patches, 3 bottles for each patch. Because the canopy is relatively low, a hole about $10 \mathrm{~cm}$ in depth was dug for placing each bottle, and the mouth

15 of bottle was about $5 \mathrm{~cm}$ above the ground. The throughfall was recorded at the same time as the stemflow.

The evaporation rate calculated by the energy balance Bowen Ratio method (Zhang, 2014; Zhang et al., 2016a) was used in the rainfall partitioning modeling. The energy balance Bowen Ratio method calculates the evaporation rate using 10 min frequency data 20 of net radiation, soil heat flux, and air temperature and humidity at two different heights, 
along with soil moisture and temperature above the layer measuring the soil heat flux. The measurement of original data and calculation process can be referred to Zhang et al. (2016a).

The canopy storage capacity was measured under artificial simulated rainfall. Firstly,

5 the stretch angle of branches of $P$. fruticosa were measured in situ. Then, they were excavated and carefully took back to the laboratory in a whole plant with some soil to assure that they were fresh. In the laboratory, branches were cut off from the base and weighed and then fixed on a wood base at their original angle. Artificial simulated rainfall was implemented immediately. After rainfall, each branch was weighed again, the 10 difference of the weight before and after the rainfall was the water the branch stored. The branch was then disassembled into stems and leaves. The leaves were scanned with a scanner to calculate the one-sided leaf area. The stem and leaves then were oven-dried and weighed. Totally, 33 branches were measured in the simulated rainfall at a rainfall intensity of $10.9 \mathrm{~mm} \mathrm{~h}^{-1}$ and a rainfall duration of $1 \mathrm{~h} .10 .9 \mathrm{~mm} \mathrm{~h}^{-1}$ is the minimum intensity that the

15 rainfall simulator could reach. Through it is much higher than the mean rainfall intensity in the experimental site, $58.6 \%$ of the rainfall amount happened in the storms with max 10 min intensity larger than $1.6 \mathrm{~mm}$ per $10 \mathrm{~min}\left(9.6 \mathrm{~mm} \mathrm{~h}^{-1}\right.$, see the following results in 3.1$)$.

The coverage was estimated by taking and interpreting photos above the canopy in different period. In the leafless period, the coverage is the stem coverage $\left(c_{s}\right)$. In the leafed 20 period, the leaf coverage $\left(c_{l}\right)$ was interpreted separately. The leaves in nearby shrub patches 
were collected at the time of collecting the stemflow and throughfall. The area of the shrub patches was measured and the leaves were scanned to calculate the one-sided leaf area. The leaf area index was calculated as the leaf area of per unit of shrub patch area. The change of the leaf area index was thought to be linear in the foliation and defoliation period.

\section{$5 \quad$ 2.3 Description and adapting of revised Gash model}

Gash et al. (1995) reformulated the original Gash model (Gash, 1975) to better descript the interception of sparse forest. The revised Gash model based on several hypotheses. (1) Rainfall in a given period is segmented to a succession of discrete events, separated by long enough gaps to allow the canopy to dry out after rainfall ceases and interception in

10 each events can be calculated separately. (2) Each rainfall event consists of a wetting up period, a saturation period and a drying out period. (3) The rainfall intensity and the evaporation rates are homogeneous during each rainfall event, and may be considered as constant in all events in the same period. (4) The amount of precipitation lost due to evaporation is related to the coverage of canopy. (5) At the beginning of each rainfall event,

15 the rainfall firstly wets the canopy, and the water captured by trunk is only diverted from canopy after the canopy is saturated. (6) The trunk evaporation only happens in the drying out period. Basing on these hypotheses, several specific canopy and atmospheric parameter are required. The required canopy parameters include the canopy storage capacity $(S)$, the trunk storage capacity $\left(S_{t}\right)$, the free throughfall coefficient $(p)$ and the canopy coverage $(c)$, 
as well as the stemflow ratio that rainfall is diverted to the trunks $\left(p_{t}\right)$. The required atmospheric parameters include incident gross precipitation $\left(P_{G}, \mathrm{~mm}\right)$, mean rainfall intensity $\left(\bar{R}, \mathrm{~mm} \mathrm{~h}^{-1}\right)$, the mean evaporation rate $\left(\bar{E}, \mathrm{~mm} \mathrm{~h}^{-1}\right)$, the amount of rainfall required to saturate the canopy $\left(P_{G}^{\prime}\right)$ and trunk $\left(P_{G}^{\prime \prime}\right)$. The $P_{G}^{\prime}$ and $P_{G}^{\prime \prime}$ are calculated with 5 the following equations:

$$
\begin{gathered}
P_{G}^{\prime}=-\bar{R} S_{c} / \overline{E_{c}} \ln \left(1-\overline{E_{c}} / \bar{R}\right) \\
P_{G}^{\prime \prime}=\left(\bar{R} /\left(\bar{R}-\overline{E_{c}}\right)\right)\left(S_{t} / p_{t}\right)+P_{G}^{\prime}
\end{gathered}
$$

where $\overline{E_{c}}$ is the mean evaporation rate of a wet canopy during a rainfall event, $\overline{E_{c}}=\bar{E} / c$;

$S_{c}$ is the canopy storage capacity per unit of stand cover area, $S_{c}=S / c$ (Gash et al., 1995).

10 The revised Gash model divides interception into several separate fractions relative to the storms processes (Table 2). The interception $(I, \mathrm{~mm})$, stemflow $(S F, \mathrm{~mm})$ and throughfall $(T F, \mathrm{~mm})$ are calculated using the following equations:

$$
\begin{gathered}
\sum_{j=1}^{n+m} I_{j}=c \sum_{j=1}^{m} P_{G j}+c \sum_{j=1}^{n}\left(\overline{E_{c j}} / \overline{R_{j}}\right)\left(P_{G}-P_{G}^{\prime}\right)+c n P_{G}^{\prime}+c q S_{t}+c p_{t} \sum_{j=1}^{n-q}\left(1-\left(\overline{E_{c j}} / \overline{R_{j}}\right)\right)\left(P_{G}-P_{G}^{\prime}\right) \\
\sum_{j=1}^{q} S F_{j}=c p_{t} \sum_{j=1}^{n-q}\left(1-\left(\overline{E_{c j}} / \overline{R_{j}}\right)\right)\left(P_{G}-P_{G}^{\prime}\right)-q c S_{t} \\
\sum_{j=1}^{n+m} T F_{j}=\sum_{j=1}^{n+m} P_{G}-\sum_{j=1}^{n+m} I_{j}-\sum_{j=1}^{q} S F_{j}
\end{gathered}
$$

To adapt the revised Gash model to the low deciduous shrub, some hypotheses should be change according to the characteristic of deciduous shrub canopy. The height of the shrub is only about $35.4 \mathrm{~cm}$. The shrub canopy evaporation has no difference from the 
stem evaporation and inter-patch herb canopy evaporation. In the leafless and regreening period, the leaves do not cover the stem completely, and rainfall can fall on the stem directly. The canopy of the P. fruticosa shrub change greatly along with foliation and defoliation. The aspect change of shrub would have great influence on the canopy coverage and canopy water storage capacity. To adapt the model, the shrub is distinguished as two part, leaf canopy and stem, and the hypotheses (4) - (6) in the revised Gash model should be change as following: (4) The evaporation from the canopy and from the ground is equal, because the height of the shrub is only about $35.4 \mathrm{~cm}$. So, the amount of precipitation lost due to evaporation is not related to the area of canopy, $\overline{E_{c}}=\bar{E}$. And the measured

10 evapotranspiration using the method of BREB (Zhang et al., 2016a) could be used as the evaporation in this paper. (5) The coverage of stem in the leafless period is $c_{s}\left(0<c_{s}<1\right)$, and the leaf coverage changes daily and is $c_{l}\left(0 \leq c_{l} \leq 1\right)$ at a special period. The rain falls on the stem directly at a probability of $\left(1-c_{l}\right) c_{s}$. The rain obtained by the stem also converts to the stemflow at a ratio of $p_{t}$. When the leaves is saturated, rainfall also diverted to the

15 stem at a ratio of $p_{t .}$ (6) The water retained on the stems may be treated in a similar manner as that retained by the leaf canopy, as assumed by van Dijk and Bruijnzeel (2001a). The stem evaporation happens in the whole rainfall period but not only in the drying out period. Another hypothesis should be added for calculating the leaf canopy storage: (7) The leaf coverage and leaf canopy storage changes daily and is a function of the leaf dry biomass 20 or leaf area, as assumed by van Dijk and Bruijnzeel (2001a). 
The amount of rainfall required to saturate the leaf canopy $\left(P_{G}^{\prime}\right)$ is calculated with following equation:

$$
P_{G, j}^{\prime}=-S_{l, j}\left(\overline{R_{j}} / \overline{E_{j}}\right) \ln \left(1-\overline{E_{j}} / \overline{R_{j}}\right)
$$

The magnitude of rainfall required to saturate the stem $\left(P_{G}^{\prime \prime}\right)$ is recalculated with the

5 following equation:

$$
P_{G, j}^{\prime \prime}=\left(S_{s} \overline{R_{j}} /\left(\overline{R_{j}}-\overline{E_{j}}\right)+c_{l, j} P_{G, j}^{\prime}\right) /\left(c_{s}+p_{t} c_{l, j}-c_{s} c_{l, j}\right)
$$

The six separate fractions of interception loss in this paper could be recalculated as Table 2, and the interception could be recalculated as the sum of these six fractions. The stemflow could be recalculated by following equation:

$$
\sum_{j=1}^{q} S F_{j}=\sum_{j=1}^{q} p_{t}\left(1-\overline{R_{j}} / \overline{E_{j}}\right)\left(c_{l, j}\left(P_{G, j}-P_{G, j}^{\prime \prime}\right)+c_{s}\left(1-c_{l, j}\right)\left(P_{G, j}-P_{G, j}^{\prime \prime}\right)\right)
$$

\section{Results}

\subsection{Meteorological and canopy parameters}

During June and October, 2012, there are altogether 80 rainfall events in the experimental site. The total rainfall amounted to $531.0 \mathrm{~mm}$, and ranged from $0.2 \mathrm{~mm}$ and $1540.0 \mathrm{~mm}$ except for a $106.2 \mathrm{~mm}$ storm of 50 years' frequency in August. The average rainfall duration and intensity were $11.17 \mathrm{~h}$ and $0.9 \mathrm{~mm} \mathrm{~h}^{-1}$. The mean max 10 min rainfall intensity is $0.8 \mathrm{~mm}$ per $10 \mathrm{~min}$ with a max of $10.4 \mathrm{~mm}$ per $10 \mathrm{~min}$, equaling $4.8 \mathrm{~mm} \mathrm{~h}^{-1}$ 
and $624.0 \mathrm{~mm} \mathrm{~h}^{-1}$, respectively. There were 12 rainfall events whose max 10 min intensity were larger than $1.6 \mathrm{~mm}$ per $10 \mathrm{~min}\left(9.6 \mathrm{~mm} \mathrm{~h}^{-1}\right)$, accounting for $311.4 \mathrm{~mm}$ and $58.6 \%$ of the total rainfall amount. Most rainfall appeared at July and August, accumulating rainfall depth of $84.4 \mathrm{~mm}$ and $248.2 \mathrm{~mm}$, respectively (Figure 1a). Of the 80 rainfall events, $37.5 \%$

5 were less than $0.5 \mathrm{~mm}$, accumulating rainfall depth $6.8 \mathrm{~mm}$; and $11.3 \%$ were $0.5-1.7$ $\mathrm{mm}$, accumulating rainfall depth $17.0 \mathrm{~mm}$ (Figure $1 \mathrm{~b}$ ).

The stem density of the P. fruticosa is 385 stems per $\mathrm{m}^{2}$. The average aboveground biomass of the P. fruticosa shrub patch in June and August was $1.03 \pm 0.39 \mathrm{~kg} \mathrm{~m}^{-2}$. For the $q$ events in a period that generated stemflow, the stemflow $\left(S F_{b}, \mathrm{ml}\right)$ generated by a branch 10 can be calculated as equation:

$$
S F_{v}=-6.26 q+1.31 P_{G}+0.18 P_{G} * M_{d}\left(R^{2}=0.90, n=38\right)
$$

The relationship between the branch water storage capacity $\left(C_{b}, \mathrm{ml}\right)$ and branch dry biomass $\left(M_{d}, \mathrm{~g}\right)$ is $C_{b}=1.10 M_{d}\left(R^{2}=0.92, n=33\right)$. The relationship between the stem water storage capacity $\left(C_{s t}, \mathrm{ml}\right)$ and stem dry mass $\left(M_{s t}, \mathrm{~g}\right)$ is $C_{s t}=0.60 M_{s t}\left(R^{2}=0.95, \mathrm{n}=33\right)$ and

15 the relationship between leaves water storage capacity $\left(C_{l f}, \mathrm{ml}\right)$ and leaves dry mass $\left(M_{l f}\right.$, g) was $C_{l f}=4.29 M_{l f}\left(R^{2}=0.92, \mathrm{n}=33\right)$. The percentage of water storage capacity ratio of stem and leaves was $48.2 \%$ and $51.8 \%$, respectively. The shrub patch water storage capacity was $1.13 \pm 0.43 \mathrm{~mm}$, and for the leaf and the stem was $0.59 \mathrm{~mm}$ and $0.55 \mathrm{~mm}$, respectively. 


\subsection{Observed rainfall partitioning pattern}

During June 1 and September 11, 2012, seven measurements contained 55 rainfall events and $484.8 \mathrm{~mm}$ rainfall were available in the experiment. The cumulative throughfall, stemflow and interception loss of the seven recorded periods equaled $141.9 \mathrm{~mm}, 239.0$

$5 \mathrm{~mm}$, and $103.9 \mathrm{~mm}$, respectively, representing $29.26 \%, 49.30 \%$, and $21.44 \%$ of gross rainfall. The linear relationship between stand stemflow $\left(S F_{s t}\right)$ and gross rainfall $\left(P_{G}\right)$ was $S F_{s t}=0.68 P_{G}-2.61 q\left(R^{2}=0.99, n=7\right)$. The $p_{t}=0.68$.

\subsection{Performance of the revised Gash model and the variable parameters Gash model}

The estimated rainfall partitioning patterns using the revised Gash model are shown in Table 4. The estimated throughfall, stemflow and interception were $124.7 \mathrm{~mm}, 246.2 \mathrm{~mm}$ and $113.9 \mathrm{~mm}$, respectively. In the whole monitoring period, the throughfall was underestimated by $12.07 \%$, and the stemflow and interception were overestimated by $3.01 \%$ and $9.6 \%$, respectively. For a special record, the estimated error was $-41.2 \% \sim-6.5 \%$, -

$155.69 \% \sim 30.86 \%$ and $-20.0 \% \sim 27.6 \%$ for the throughfall, stemflow and interception, respectively. According to the classified level of models (Muzylo et al., 2009), the revised Gash model in this paper was good $(5 \%<$ error $<10 \%)$ for interception, very good $(1 \%<$ error $<5 \%)$ for stemflow, and fair $(10 \%<$ error $<30 \%)$ for the throughfall.

The estimated rainfall partitioning pattern using the variable parameters Gash model 
for deciduous shrub is presented in Table 5. Compared to the former results (Table 4), the performance of the new model are much better. The total estimated errors are only $-1.2 \%$, $-0.8 \%$ and $3.5 \%$ for the throughfall, stemflow and interception, respectively. According to the classified level of models (Muzylo et al., 2009), the model got in this paper was very $5 \operatorname{good}(1 \%<$ error $<5 \%)$ for throughfall, stemflow and interception.

Rainfall partitioning predicted by the revised Gash model and the variable parameters Gash model were shown in Table 6. The difference of estimated interception by two models was only $6.4 \mathrm{~mm}$ or $1.3 \%$ of gross precipitation. But the contribution of interception predicted by two models has greatly difference in the $I_{s}$ and $I_{s t}$. The $I_{s t}$

10 predicted by the variable parameters Gash model is $10.2 \mathrm{~mm}$ more than that predicted by the revised Gash model, which accounting for $9.8 \%$ of the total observed interception. Meanwhile, the $I_{s}$ predicted by the variable parameters Gash model is $15.0 \mathrm{~mm}$ lower than that predicted by the revised Gash model, which occupying $14.4 \%$ of the total observed interception.

\section{$15 \quad 3.4$ Parameter sensitivities}

Sensitivity analyses of canopy and meteorological parameters were conducted to determine their influence degree on the rainfall partitioning pattern (Figure 2). $c, \bar{E}, S_{c}, S_{t}$ and $p_{t}$ had positive relationship with interception, whereas $\bar{R}$ had negative relationship with interception. The three most sensitive parameters of interception were $\bar{R}, c$ and $\bar{E}$. If 
the $\bar{R}$ decreased by $50 \%$, the interception would increase by $46.95 \%$; and if the $c$ and $\bar{E}$ decreased by $50 \%$, the interception would decrease by $40.13 \%$ and $27.02 \%$, respectively. $c, \bar{R}$ and $p_{t}$ were positively correlated with estimated interception loss, whereas, $\bar{E}, S_{c}$ and $S_{t}$ were negatively correlated with stemflow yield.

5 The three most sensitive parameters of stemflow yield were $p_{t}, c$ and $\bar{R}$ when the parameters decreased. If the $p_{t}, c$ and $\bar{R}$ decrease by $50 \%$, the stemflow would decrease by $53.74 \%, 54.18 \%$ and $17.29 \%$, respectively. When the parameters increase, the stemflow is mostly sensitive to the change of $p_{t}, \bar{E}$ and $\bar{R}$. If the $p_{t}$ and $\bar{R}$ increase by $50 \%$, the stemflow would increase by $54.33 \%$ and $6.65 \%$, respectively; and if the $\bar{E}$ increased by $1050 \%$, the stemflow would decrease by $8.95 \%$.

$c, \bar{E}, S_{c}, S_{t}$ and $p_{t}$ were negatively correlated with estimated throughfall, whereas $\bar{R}$ were positively correlated with estimated throughfall. The three most sensitive parameters of throughfall were $c, p_{t}$ and $\bar{R}$ if the parameters decrease. If the $c$ and $p_{t}$ decrease by $50 \%$, the throughfall would increase by $156.06 \%$ and $111.81 \%$, respectively. If the parameters

15 increase, the throughfall is most sensitive to the change of $p_{t}, \bar{E}$ and $\bar{R}$. If the $p_{t}$ and $\bar{E}$ increase by $50 \%$, the throughfall would decrease by $111.81 \%$ and $8.76 \%$, respectively; and if the $\bar{R}$ increase by $50 \%$, the throughfall would increase $6.27 \%$.

Therefore, the rainfall partitioning pattern in the shrub patch is very sensitive to the change of canopy coverage, evaporation, rainfall intensity and stemflow ratio. The 20 accurate measurement or estimate of these parameters has great influence on the 
effectiveness on the model.

\section{Discussion}

\subsection{Parameters}

The parameters sensitivities of interception from the revised Gash model for

5 interception has been analyzed by Limousin et al. (2008), Sun et al. (2014), Su et al. (2016a). The results in this paper are in accordance with their results that the atmospheric $\bar{E}$ and $\bar{R}$ and canopy parameter $c$ and $S$ are the most sensitive factors of rainfall partitioning modeling. It would not be discussed here. The parameters sensitivities of the stemflow and throughfall were not reported formerly. The stemflow was sensitive to the

$10 p_{t}, c, \bar{E}$ and $\bar{R}$. Because the stemflow is the section of interception that runs down the stem, the parameters that affect the interception also affect the stemflow. The proportion $p_{t}$ also has important in the stemflow of course, it determines the percentage of interception that converts to stemflow. The throughfall is the residue of gross precipitation minus the interception and stemflow, and it is mostly sensitive to the parameter that the interception

15 and stemflow is most sensitive to.

Due to the parameters sensitivities of the revised Gash model, it is necessary to set different parameters at shorter periods according to the variation of vegetation and rainfall (Jackson, 2000; Deguchi et al., 2006; Herbst et al., 2008; Sraj et al., 2008; Muzylo et al., 2012), especially for which interception and stemflow is impressionable. Deciduous 
vegetation has great changes in canopy with leafed and leafless period and their transition within a year. Their canopy parameters such as coverage, leaf canopy storage capacity, etc., should not be treated as constants in the growing season due to foliation and defoliation. Especially, the interception, stemflow and throughfall were very sensitive to the canopy coverage.

Canopy coverage is a very important parameter in the analytical model, and many model parameters (e.g. $\overline{E_{c}}, S_{c}, p, p t$ ) have linear relationship with the canopy coverage (Gash et al., 1995; Limousin et al., 2008). The reduction of the canopy coverage would decrease the interception (Limousin et al., 2008). This is quite direct results because when

10 the canopy coverage decrease, the areas capture the rainfall was reduced, and then the interception decreased. As the sensitive analysis, the decrease of coverage could result in the reduction of stemflow and the increase of free throughfall. The stemflow are the part of interception that run down the stem, so if the interception reduces, the stemflow would reduce. The coverage reduce meant the increased of the free throughfall coefficient, which

15 could be assumed to be one minus coverage ( $\mathrm{Su}$ et al., 2016b). The coverage can be estimated using hemispherical photographs taken by a fish eye lens camera or a plant canopy analyzer (Mcjannet et al., 2007; Limousin et al., 2008; Muzylo et al., 2012). If the coverage is not directly measured, it can be assumed to be one minus free throughfall coefficient (Shi et al., 2010; Fan et al., 2014). The free throughfall coefficient can be 20 estimated as the slope of the linear regression of throughfall against gross precipitation for 
small rainfall events that were insufficient to exceed canopy storage capacity (Jackson, 1975; Shi et al., 2010; Fan et al., 2014). However, these two methods are not suitable for the low deciduous shrub. The height of the shrub in this study is too low to use the fish eye lens camera or the plant canopy analyzer. Because the coverage and canopy storage

5 capacity changed continuously along with the foliation and defoliation, it was difficult to collect enough throughfall data to get the regression equation for a special period, especially in the arid and semiarid region with limited rainfall events. So, basal coverage of the stem in the dormant period and of the max coverage in leaf luxuriating period were estimated using photographs. And the coverage in transition period was link to the leaf 10 area index. This method could get the accurate coverage in the whole research period.

The canopy storage capacity is the most important parameter in the interception modeling (Aston, 1979). The determination of the canopy water storage capacity has great influence on the accuracy of the rainfall partitioning modeling (Limousin et al., 2008). Precise measurement of the canopy water storage capacity is the precondition of the 15 prediction accuracy. Several methods were found to estimate the canopy water storage capacity, as the negative intercept of the regression of gross precipitation against the sum of throughfall and stemflow (Wallace and Mcjannet, 2006), or as the negative intercept divided by one minus drainage partitioning coefficient $\left(p_{d}\right)$ of the linear regression of throughfall against gross precipitation, fitted with a pre-established slope of $\left(1-c p_{d}\right)$

20 (Valente et al., 1997; Muzylo et al., 2012). Some study emphasized that rainfall for 
calculating the canopy storage capacity should be saturating events (Klaassen et al., 1998; Carlyle-Moses and Price, 1999; Limousin et al., 2008). Some researchers also measured the canopy storage capacity directly (Wang et al., 2006; Wang and Zhang, 2006). Direct measurement of canopy capacity was an all-consuming task and was not common used in

5 forest rainfall partitioning modeling. For the shrub, it could be easier to measure the canopy capacity directly because the magnitude of the shrub is much smaller than the forest. In this paper, the water storage capacity was measured under artificial simulated rainfall. As the rainfall intensity has influence on the canopy storage capacity (Wang et al., 2012), the simulated rainfall method is much authentic than the immersion method used by Wang 10 and Zhang (2006) which could not consider the influence of rainfall intensity. The simulated rainfall method treated the shrub in a close to the real condition, the storage capacity got in this method should be much true. The simulated rainfall is more effective at wetting by formatting coherent droplets (Beysens et al., 1991). The water storage capacities measured by immersion were lower than the values obtained in the simulated 15 rainfall experiments (Garcia-Estringana et al., 2010). Canopy storage capacity was assumed to be linearly related to leaf area index, and can be expressed as the product of specific leaf storage and leaf area index (Liu, 1998; van Dijk and Bruijnzeel, 2001a). So, by testing the specific leaf storage capacity in laboratory and monitoring the leaf area index or leaf biomass in different period, the canopy storage capacity can be estimated in a 20 special period. 
The stem storage capacity might be somewhat less important than the canopy storage capacity. In most reported study, the stem storage capacity was much smaller than the canopy storage capacity (Carlyle-Moses and Price, 2007; Muzylo et al., 2012). The stem storage capacity could be estimated as the negative intercept of the linear regression of the stemflow against gross precipitation (Su et al., 2016a). In this paper, the stem storage capacity was measured along with the leaf canopy storage capacity under simulated rainfall. The leaf canopy storage capacity and stem storage capacity were $0.59 \mathrm{~mm}$ and $0.55 \mathrm{~mm}$, respectively. Unlike former reports, the leaf canopy storage capacity of the $P$. fruticosa shrub was only a little larger than the stem storage capacity. There were no former 10 reports about the water storage capacity of the $P$. fruticosa shrub. The specific leaf storage capacity of A. ordosica, H. scoparium and S. psammophila were $0.68,0.44$ and $0.31 \mathrm{~g} \mathrm{~g}^{-1}$ dry weight, respectively (Yang, 2010), and they were $0.51,0.41$ and $0.73 \mathrm{~g} \mathrm{~g}^{-1}$ of specific canopy storage capacity for C. korshinskii, H. scoparium, and A. ordosica, respectively (Wang et al., 2012), and $0.49-0.94 \mathrm{~mm}$ and $0.16-0.78 \mathrm{~mm}$ for the $C$. vulgaris and $P$.

15 aquilinum, respectively (Leyton et al., 1967; Hall, 1985; Pitman, 1989). The specific leaf storage capacity of the P. fruticosa shrub was higher than those reported results, but fell into the range reported by Garcia-Estringana et al. (2010). The reason could be that in this paper, the specific storage capacity of leaf and stem were considered separately, the specific storage capacity of stem was similar as the former reported results of shrubs,

20 whereas, the specific storage capacity of leaf was higher than reported results, because the 
leaf had larger specific surface area per dry mass. The storage capacity of stem was almost as high as that of leaf may be explained by the special bark of the P. fruticosa. The bark of this shrub is thick, papery and soft (Figure 3b), and can absorb a lot of water. Such a bark may be the mechanism the shrub adapting the cold weather. The leaf area has great

5 influence on the canopy coverage, canopy water storage capacity and therefore on the interception loss, higher leaf area would result in more interception loss (Gómez et al., 2001; van Dijk and Bruijnzeel, 2001a; Deguchi et al., 2006). So, it is important to monitor the process of canopy structure changes.

The revised Gash model is sensitive to rainfall intensity and evaporation rate. This 10 sensitivity does not differ between seasons regardless of the structural changes in vegetation (Muzylo et al., 2012). The rainfall intensity is often observed by auto-record rainfall gauge and it has no subjective factor. The evaporation has different calculation method and could be a possible source of error in modeling rainfall partitioning (Llorens, 1997). The evaporation could be estimated by the Penman-Monteith equation (P-M 15 equation) (Rutter et al., 1971; Carlyle-Moses and Gash, 2011), or estimated as the slope of the regression of interception against gross precipitation (Pereira et al., 2009), or was obtained from optimization procedure where evaporation was adjusted to minimize the root mean square difference between the daily modelled and measured interception (Wallace and Mcjannet, 2008). When using the P-M equation, the accurate determination

20 of the aerodynamic resistance is a great difficult, while the evaporation is sensitive to the 
Hydrol. Earth Syst. Sci. Discuss., doi:10.5194/hess-2016-589, 2016

Manuscript under review for journal Hydrol. Earth Syst. Sci.

Published: 8 December 2016

(c) Author(s) 2016. CC-BY 3.0 License.
Hydrology and

Earth System

Sciences

Discussions

aerodynamic resistance (van Dijk et al., 2015). The aerodynamic component of evaporation is typically larger than the radiation component (van Dijk et al., 2015). Evaporation estimated by the P-M equation was thought to be the main weakness of the Gash models (Zhang et al., 2006), and advanced measurement methods should be used to

5 estimate the evaporation rate in the revised Gash model ( $\mathrm{Su}$ et al., 2016a). Eddycovariance technique has been regarded as the best method to directly measure evapotranspiration, and was used in the revised Gash model by Zhang et al. (2006), but its measurements during rainfall were questionable (Wang and Dickinson, 2012). The Bowen ratio system is a reliable and oecumenical method to monitor the evaporation (Wang and

10 Dickinson, 2012). In this paper, the evaporation data of energy balance Bowen ratio method from Zhang (2014), Zhang et al. (2016a) was used in modeling rainfall partitioning. The average evapotranspiration in the $P$. fruticosa shrub meadow was $0.11 \mathrm{~mm} \mathrm{~h}^{-1}$ during the experimental period. It was relatively lower compared to worldwide evaporation rate calculated by revised Gash model, more than $87 \%$ papers reported evaporation higher than

$150.11 \mathrm{~mm} \mathrm{~h}^{-1}$ (Murakami, 2007). This is partly relative to the low vegetation height and high-altitude cold weather with low temperature. The hourly evaporation varied greatly in different time, ranging from -0.04 to $0.87 \mathrm{~mm} \mathrm{~h}^{-1}$, controlled mainly by radiation (Zhang, 2014; Zhang et al., 2016a). The variation of the evaporation and its importance imply that it should not be set as a constant. With the event-based evaporation, the results of rainfall 20 partitioning modeling could be improved. 
The variable parameters Gash model is relatively more complex than the original models, but has better performance in more complex conditions. The input data demands are more than the revised Gash model, but are not hard to collect at present. The changes in coverage and leaf canopy storage depending on the seasonal aspects of deciduous shrub,

5 as well as rain water captured by the stem directly and evaporated during the whole rainfall period has been included in and is considered a vital conceptual improvement. These improvements are of great significance in deciduous shrub stands which have a great change in coverage and leaf storage capacity relative to their leaf area index which is determined by the foliation and defoliation. These additions along with the consideration

10 for the stem water capturing and evaporation have resulted in the interception, stemflow and throughfall simulations all being very good. The introduction of new parameters and process to the model might violate the principle of "requisite simplicity" for any model, but considering the conceptual clarity and scientific rigor, the new approach adopted in the paper could be meaningful. Extending the variable parameters Gash model to other

15 ecosystems with different canopy structure and weather condition will show whether it works.

\subsection{Rainfall partitioning in deciduous shrubs}

The rainfall fell on the $P$. fruticosa canopy was mainly redistributed to stemflow, accounting for $49.3 \%$. In most researches, the main part of rainfall partitioning is 
Hydrol. Earth Syst. Sci. Discuss., doi:10.5194/hess-2016-589, 2016

Manuscript under review for journal Hydrol. Earth Syst. Sci.

Published: 8 December 2016

(c) Author(s) 2016. CC-BY 3.0 License.

(c) (1)
Hydrology and

Earth System

Sciences

Discussions

throughfall (Llorens and Domingo, 2007). The stemflow took the main part in the $P$. fruticosa partly because the research space scale is based on the shrub patch, and the interpatch is not considered. In the individual shrub scale, Belmonte Serrato and Romero Diaz (1998) also reported an as high as $43.3 \%$ of relative stemflow production. Another reason

5 is the stem density of the P. fruticosa is as high as 385 stems per $\mathrm{m}^{2}$, and its canopy structures that promote stemflow yield. The stem was nearly vertical and rarely warped above the ground, and their sub stems have small angles (Figure 3a).

There is no former report of the stemflow measurement of the P. fruticosa, whereas there were two researches on the interception of the P. fruticosa. $30.56 \%$ and $10.42 \%$ of 10 gross precipitation was intercepted by the shrub canopy as reported by Nie (2009), Li (2015). The relative interception found in the present study is $21.4 \%$ and is among the former observed range. This value is common among the former reports (Table 1).

$I_{s}$ and $I_{a}$ calculated from the revised Gash model took $53.4 \%$ and $20.1 \%$ of interception of the $P$. fruticosa shrub. It is common that the $I_{s}$ and $I_{a}$ is the main part of the interception

15 calculated from the revised Gash model. In the 32 former results, the mean $I_{s} 42.8 \%$, ranging from $9.0 \%$ to $91.2 \%$, and the mean $I_{a}$ is $36.7 \%$, ranging from $4.0 \%$ to $74.0 \%$ (Table 7). These results also reveal why the interception is sensitive to the $\bar{E}$ and $S_{c}$.

The $I_{s t}$ calculated from the revised Gash model took $17.5 \%$ of the interception. This value is much higher than the average value in the 32 former results, $4.5 \%$ of the 20 interception (Table 7). The reason lies in the high stem storage capacity of the $P$. fruticosa. 
The stem storage capacity $(0.55 \mathrm{~mm})$ is almost as high as the leaf canopy storage capacity $(0.59 \mathrm{~mm})$.

The most difference of the compositions of the interception between the variable parameters Gash model and the revised Gash model lies in the $I_{s}$ and $I_{s t}$ (Table 6). The $I_{s}$

5 calculated by the variable parameters Gash model is smaller than that calculated by the revised Gash model, and the $I_{s t}$ calculated by the variable parameters Gash model is larger than that calculated by the revised Gash model. This is partly because the variable parameters Gash model assumed that the water captured by the stem was treated as that captured by the canopy. In the revised Gash model, water captured by the stem is all from

10 the canopy interception and only evaporated in the drying out period after the end of rainfall. In the variable parameters model, rain could drop on the stem directly, and water captured by stems could evaporate in and after the rainfall. We thought the improved model is more near the actual condition, especially, in the leafless period when the stem was exposed to the atmosphere completely. The assumption in the variable parameters model

15 increased income and the evaporation time of the water captured by stem, thus the $I_{s t}$ increased.

\section{Conclusion}

This study also confirms that rainfall partitioning by the canopy plays a significant role in ecosystem hydrological cycle. $21.44 \%$ of gross rainfall was intercepted by the canopy, 
$29.26 \%$ and $49.30 \%$ of gross rainfall was available water that free fell and drained along the stem into the soil during the growing season of 2012. The interception proportion was similar to the values reported for other arid and semiarid shrubs. However, while the stemflow was higher than former reported values, partly because their high stem density

5 and canopy structures that promote stemflow yield.

The variable parameters Gash model adapted for the deciduous shrub is presented with hypotheses more in accordance with the real condition and has better performance than the revised Gash model. The revised Gash model underestimated the throughfall by $12.07 \%$, and overestimated the stemflow and interception by $3.01 \%$ and $9.6 \%$, respectively.

10 Whereas, the variable parameters Gash model performed all very well in the prediction of throughfall, stemflow and interception, with only $-1.2 \%,-0.8 \%$ and $3.5 \%$ estimated errors, respectively.

The wet leaf canopy evaporation during storms accounted for $42.6 \%$ of total interception loss, implying the importance of the evaporation rate in rainfall partitioning

15 modelling. The interception loss via stem evaporation estimated by variable parameters Gash model is much higher than the proportion estimated by the revised Gash model. This proportion is the most difference between these two models. The results reveal the important of the stem evaporation in the interception loss of the deciduous shrubs.

\section{Acknowledgements}


Hydrol. Earth Syst. Sci. Discuss., doi:10.5194/hess-2016-589, 2016

Manuscript under review for journal Hydrol. Earth Syst. Sci.

Published: 8 December 2016

(c) Author(s) 2016. CC-BY 3.0 License.

This work was supported by the National Science Foundation of China (Grant No. NSFC 41501295, 41130640 and 91425301), SPICC Program, projects from State Key Laboratory of Earth Surface Processes and Resource Ecology.

\section{References}

Aboal J. R., Jimenez M. S., Morales D., Hernandez J. M.: Rainfall interception in laurel forest in the Canary Islands, Agr. Forest Meteorol., 97(2), 73-86, 1999.

Aston A. R.: Rainfall interception by eight small trees, J. Hydrol., 42(3), 383-396, 1979.

Belmonte Serrato F., Romero Diaz A.: A simple technique for measuring rainfall interception by small shrub: "interception 10 flow collection box", Hydrol. Process., 12(3), 471-481, 1998.

Beysens D., Steyer A., Guenoun P., Fritter D., Knobler C. M.: How does dew form? Phase Transit., 31(1-4), 219-246, 1991.

Bryant M. L., Bhat S., Jacobs J. M.: Measurements and modeling of throughfall variability for five forest communities in the southeastern us, J. Hydrol., 312(1-4), 95-108, 2005.

Carlyle-Moses D. E., Price A. G.: An evaluation of the Gash interception model in a northern hardwood stand, J. Hydrol., 15 214(1-4), 103-110, 1999.

Carlyle-Moses D. E., Price A. G.: Modelling canopy interception loss from a madrean pine-oak stand, northeastern Mexico, Hydrol. Process., 21(19), 2572-2580, 2007.

Carlyle-Moses D. E.: Throughfall, stemflow, and canopy interception loss fluxes in a semi-arid Sierra Madre Oriental matorral community, J. Arid Environ., 58(2), 181-202, 2004.

20 Carlyle-Moses D., Gash J. H. C.: Rainfall interception loss by forest canopies, 407-423, 2011.

Crockford R. H., Richardson D. P.: Partitioning of rainfall into throughfall, stemflow and interception: effect of forest type, ground cover and climate, Hydrol. Process., 14(16-17), 2903-2920, 2000.

Deguchi A., Hattori S., Park H. T.: The influence of seasonal changes in canopy structure on interception loss: application of the revised Gash model, J. Hydrol., 318(1-4), 80-102, 2006.

25 Domingo F., Sánchez G., Moro M. J., Brenner A. J., Puigdefábregas J.: Measurement and modelling of rainfall interception by three semi-arid canopies, Agr. Forest Meteorol., 91(3 - 4), 275-292, 1998.

Dunkerley D.: Measuring interception loss and canopy storage in dryland vegetation: a brief review and evaluation of available 
Hydrol. Earth Syst. Sci. Discuss., doi:10.5194/hess-2016-589, 2016

Manuscript under review for journal Hydrol. Earth Syst. Sci.

research strategies, Hydrol. Process., 14(4), 669-678, 2000.

Dykes A. P.: Rainfall interception from a lowland tropical rainforest in Brunei, J. Hydrol., 200(1-4), 260-279, 1997.

Fan J., Oestergaard K. T., Guyot A., Lockington D. A.: Measuring and modeling rainfall interception losses by a native banksia woodland and an exotic pine plantation in subtropical coastal Australia, J. Hydrol., 515, 156-165, 2014.

Garcia-Estringana P., Alonso-Blázquez N., Alegre J.: Water storage capacity, stemflow and water funneling in Mediterranean shrubs, J. Hydrol., 389(3-4), 363-372, 2010.

Gash J. H. C., Lloyd C. R., Lachaud G.: Estimating sparse forest rainfall interception with an analytical model, J. Hydrol., 170(1), 79-86, 1995.

Gash J. H. C.: An analytical model of rainfall interception by forests, Q. J. Roy. Meteor. Soc., 105(443), 43-55, 1979.

10 Gómez J. A., Giráldez J. V., Fereres E.: Rainfall interception by olive trees in relation to leaf area, Agr. Water Manage., 2001.

Hall R. L.: Further interception studies of heather using a wet surface weighing lysimeter system, J. Hydrol., 81, 193-210, 1985.

Herbst M., Rosier P. T. W., Mcneil D. D., Harding R. J., Gowing D. J.: Seasonal variability of interception evaporation from the canopy of a mixed deciduous forest, Agr. Forest Meteorol., 148(11), 1655-1667, 2008.

15 Jackson I. J.: Relationships between rainfall parameters and interception by tropical forest, J. Hydrol., 24(3), 215-238, 1975.

Jackson N. A.: Measured and modelled rainfall interception loss from an agroforestry system in Kenya, Agr. Forest Meteorol., 100(4), 323-336, 2000.

Jian S., Zhao C., Fang S., Yu K., Wang Y., Liu Y., Zheng X., Peng S.: Characteristics of rainfall interception by Caragana korshinskii and Hippophae rhamnoides in Loess Plateau of Northwest China, Chinese Journal of Applied Ecology, 23(9), 2383-2389, 2012 (in Chinese with English abstract).

Jian S., Zhao C., Fang S., Yu K.: Characteristics of caragana korshinskii and hippophae rhamnoides stemflow and their significance in soil moisture enhancement in loess plateau, China, J. Arid Land, 6(1), 105-116, 2014.

Johnson M. S., Lehmann J.: Double-funneling of trees: stemflow and root-induced preferential flow, Ecoscience, 13(3), 324333, 2009.

25 Klaassen W., Bosveld F., de Water E.: Water storage and evaporation as constituents of rainfall interception, J. Hydrol., 212(14), 36-50, 1998.

Levia D. F., Frost E. E.: A review and evaluation of stemflow literature in the hydrologic and biogeochemical cycles of forested and agricultural ecosystems, J. Hydrol., 274(1-4), 1-29, 2003.

Leyton L., Reynolds E. R. C., Tompson F. B.: Rainfall interception in forest and moorland, 163-178, 1967.

Li L., Li X., Zhang S., Jiang Z., Zheng X., Hu X., Huang Y.: Stemflow and its controlling factors in the subshrub artemisia 
Hydrol. Earth Syst. Sci. Discuss., doi:10.5194/hess-2016-589, 2016

Manuscript under review for journal Hydrol. Earth Syst. Sci.

Published: 8 December 2016

(c) Author(s) 2016. CC-BY 3.0 License.

ordosica during two contrasting growth stages in the mu us sandy land of northern China, Hydrol. Res., 47(2), 409-418, 2016.

Li W. J.: Characteristic of rainfall interception by shrub in Tianlaochi catchment in the upper reaches of Heihe River, Lanzhou University, 2015 (in Chinese with English abstract).

Li X., Liu L., Gao S., Ma Y., Yang Z.: Stemflow in three shrubs and its effect on soil water enhancement in semiarid loess region of China, Agr. Forest Meteorol., 148(10), 1501-1507, 2008.

Li X., Yang Z., Li Y., Lin H.: Connecting ecohydrology and hydropedology in desert shrubs: stemflow as a source of preferential flow in soils, Hydrol. Earth Syst. Sc., 13(7), 1133-1144, 2009.

Li X.: Mechanism of coupling, response and adaptation between soil, vegetation and hydrology in arid and semiarid regions, Scientia Sinica Terrae, 41(12), 1721-1730, 2011 (in Chinese with English abstract).

Limousin J., Rambal S., Ourcival J., Joffre R.: Modelling rainfall interception in a Mediterranean quercus ilex ecosystem: lesson from a throughfall exclusion experiment, J. Hydrol., 357(1-2), 57-66, 2008.

Link T. E., Unsworth M., Marks D.: The dynamics of rainfall interception by a seasonal temperate rainforest, Agr. Forest Meteorol., 124(3-4), 171-191, 2004.

15 Liu S. G.: Estimation of rainfall storage capacity in the canopies of cypress wetlands and slash pine uplands in north-central Florida, J. Hydrol., 207(1-2), 32-41, 1998.

Llorens P., Domingo F.: Rainfall partitioning by vegetation under Mediterranean conditions. A review of studies in Europe, J. Hydrol., 335(1-2), 37-54, 2007.

Llorens P.: Rainfall interception by a pinus sylvestris forest patch overgrown in a Mediterranean mountainous abandoned area ii. Assessment of the applicability of Gash's analytical model, J. Hydrol., 199(3-4), 346-359, 1997.

Ma Y., Gao S., Li X., Lu R., Zhang S., Li G.: Rainfall Canopy Partitioning and Its Influencing Factors of Riparian Shrub in the Alpine Region, Journal of Desert Research, 32(4), 963-971, 2012 (in Chinese with English abstract).

Martinez-Meza E., Whitford W. G.: Stemflow, throughfall and channelization of stemflow by roots in three Chihuahuan desert shrubs, J. Arid Environ., 32(3), 271-287, 1996.

25 Mauchamp A., Janeau J. L.: Water funnelling by the crown of flourensia cernua, a Chihuahuan desert shrub, J. Arid Environ., 25(3), 299-306, 1993.

Mcjannet D., Wallace J., Reddell P.: Precipitation interception in Australian tropical rainforests: i. Measurement of stemflow, throughfall and cloud interception, Hydrol. Process., 21(13), 1692-1702, 2007.

Murakami S.: Application of three canopy interception models to a young stand of Japanese cypress and interpretation in terms of interception mechanism, J. Hydrol., 342(3-4), 305-319, 2007. 
Hydrol. Earth Syst. Sci. Discuss., doi:10.5194/hess-2016-589, 2016

Manuscript under review for journal Hydrol. Earth Syst. Sci.

Published: 8 December 2016

(c) Author(s) 2016. CC-BY 3.0 License.

Muzylo A., Llorens P., Valente F., Keizer J. J., Domingo F., Gash J. H. C.: A review of rainfall interception modelling, J. Hydrol., 370(1-4), 191-206, 2009.

Muzylo A., Valente F., Domingo F., Llorens P.: Modelling rainfall partitioning with sparse Gash and rutter models in a downy oak stand in leafed and leafless periods, Hydrol. Process., 26(21), 3161-3173, 2012.

Návar J., Bryan R.: Interception loss and rainfall redistribution by three semi-arid growing shrubs in northeastern Mexico, J. Hydrol., 1990.

Nie X. H.: Study on water conservation function of shrub in Qilian Mountains, Gansu Agricultural University, 2009 (in Chinese with English abstract).

Owens M. K., Lyons R. K., Alejandro C. L.: Rainfall partitioning within semiarid juniper communities: effects of event size and canopy cover, Hydrol. Process., 20(15), 3179-3189, 2006.

Peng H., Li X., Tong S.: Effects of shrub (Caragana microphalla Lain) encroachment on water redistribution and utilization in the typical steppe of Inner Mongolia, Acta Ecologica Sinica, 34(9), 2256-2265, 2014 (in Chinese with English abstract).

Pereira F. L., Gash J. H. C., David J. S., David T. S., Monteiro P. R., Valente F.: Modelling interception loss from evergreen oak Mediterranean savannas: application of a tree-based modelling approach, Agr. Forest Meteorol., 149(3-4), 680-688, 2009.

Pitman J. I.: Rainfall interception by bracken in open habitats - relations between leaf area, canopy storage and drainage rate, J. Hydrol., 105(3-4), 317-334, 1989.

Rutter A. J., Kershaw K. A., Robins P. C., Morton A. J.: A predictive model of rainfall interception in forests, 1. Derivation of the model from observations in a plantation of Corsican pine, Agricultural Meteorology, 9(71), 367-384, 1971.

Rutter A. J., Morton A. J., Robins P. C.: A predictive model of rainfall interception in forests. Ii. Generalization of the model and comparison with observations in some coniferous and hardwood stands, J. Appl. Ecol., 12(1), 367-380, 1975.

Shi Z., Wang Y., Xu L., Xiong W., Yu P., Gao J., Zhang L.: Fraction of incident rainfall within the canopy of a pure stand of pinus armandii with revised Gash model in the Liupan mountains of China, J. Hydrol., 385(1-4), 44-50, 2010.

Sraj M., Brilly M., Mikos M.: Rainfall interception by two deciduous Mediterranean forests of contrasting stature in Slovenia, Agr. Forest Meteorol., 148(1), 121-134, 2008.

Su L., Xu W., Zhao C., Xie Z., Ju H.: Inter- and intra-specific variation in stemflow for evergreen species and deciduous tree species in a subtropical forest, J. Hydrol., 537, 1-9, $2016 \mathrm{~b}$.

Su L., Zhao C., Xu W., Xie Z.: Modeling interception loss using the revised Gash model: a case study in a mixed evergreen and deciduous broadleaved forest in China, Ecohydrology, 2016a.

Sun X., Onda Y., Kato H., Gomi T., Komatsu H.: Effect of strip thinning on rainfall interception in a Japanese cypress 
Hydrol. Earth Syst. Sci. Discuss., doi:10.5194/hess-2016-589, 2016

Manuscript under review for journal Hydrol. Earth Syst. Sci.

Published: 8 December 2016

(c) Author(s) 2016. CC-BY 3.0 License.

plantation, J. Hydrol., 525, 607-618, 2015.

Sun X., Onda Y., Kato H.: Incident rainfall partitioning and canopy interception modeling for an abandoned Japanese cypress stand, J. Forest Res.-Jpn, 19(3), 317-328, 2014.

Valente F., David J. S., Gash J.: Modelling interception loss for two sparse eucalypt and pine forests in central portugal using reformulated Rutter and Gash analytical models, J. Hydrol., 190(1-2), 141-162, 1997.

van Dijk A. I. J. M., Gash J. H., van Gorsel E., Blanken P. D., Cescatti A., Emmel C., Gielen B., Harman I. N., Kiely G., Merbold L., Montagnani L., Moors E., Sottocornola M., Varlagin A., Williams C. A., Wohlfahrt G.: Rainfall interception and the coupled surface water and energy balance, Agr. Forest Meteorol., 214, 402-415, 2015.

van Dijk A., Bruijnzeel L. A.: Modelling rainfall interception by vegetation of variable density using an adapted analytical model. Part 1. Model description, J. Hydrol., 247(3-4), 230-238, 2001a.

van Dijk A., Bruijnzeel L. A.: Modelling rainfall interception by vegetation of variable density using an adapted analytical model. Part 2. Model validation for a tropical upland mixed cropping system, J. Hydrol., 247(3-4), 239-262, $2001 \mathrm{~b}$.

Wallace J., Mcjannet D.: Modelling interception in coastal and montane rainforests in northern Queensland, Australia, J. Hydrol., 348(3-4), 480-495, 2008.

15 Wallace J., Mcjannet D.: On interception modelling of a lowland coastal rainforest in northern Queensland, Australia, J. Hydrol., 329(3-4), 477-488, 2006.

Wang K. C., Dickinson R. E.: A review of global terrestrial evapotranspiration: observation, modeling, climatology, and climatic variability, Rev. Geophys., 50(RG2005), 2012.

Wang X. P., Wang Z. N., Berndtsson R., Zhang Y. F., Pan Y. X.: Desert shrub stemflow and its significance in soil moisture replenishment, Hydrol. Earth Syst. Sc., 2011.

Wang X., Zhang Y. P., Liu W. J.: Modeling canopy rainfall interception of a tropical seasonal rainforest in Xishuangbanna,Southwest China, Acta Ecologica Sinica, (3), 722-729, 2006 (in Chinese with English abstract).

Wang X., Zhang Y., Hu R., Pan Y., Berndtsson R.: Canopy storage capacity of xerophytic shrubs in northwestern China, J. Hydrol., 454-455, 152-159, 2012.

25 Wang X., Zhang Y., Wang Z., Pan Y., Hu R., Li X., Zhang H.: Influence of shrub canopy morphology and rainfall characteristics on stemflow within a revegetated sand dune in the Tengger desert, NW China, Hydrol. Process., 27(10), 1501-1509, 2013.

Wang X., Zhang Y.: Canopy rainfall storage capacity of tropical seasonal rainforest and rubber plantation in Xishuangbanna, Chinese Journal of Applied Ecology, 17(10), 1782-1788, 2006 (in Chinese with English abstract).

Wang Z. N., Wang X. P., Liu B.: Rainfall and soil moisture redistribution induced by xerophytic shrubs in an arid desert 
Hydrol. Earth Syst. Sci. Discuss., doi:10.5194/hess-2016-589, 2016

Manuscript under review for journal Hydrol. Earth Syst. Sci.

Published: 8 December 2016

(c) Author(s) 2016. CC-BY 3.0 License.

ecosystem, Chinese Journal of Applied Ecology, 27(3), 755-760, 2016 (in Chinese with English abstract).

Xu X., Yan P., Guo S., Chai C.: The Interception Loss of Rainfall by Three Sand-fixing Shrubs at the Fringe of Minqin Oasi, Journal of Desert Research, 33(1), 141-145, 2013 (in Chinese with English abstract).

Yang Z., Li X., Sun Y., Liu L., Zhang X., Ma Y.: Characteristics of rainfall interception and stemflow for Salix psammophila in Maowusu sandland, Northwest China, Advances in Water Science, 19(5), 693-698, 2008 (in Chinese with English abstract).

Yang Z.: Rainfall partitioning process and its effects on soil hydrological processes for sand-fixed shrubs in Mu Us sandy land, northwest China, Beijing Normal University, 2010 (in Chinese with English abstract).

Yuan C., Gao G., Fu B.: Stemflow of a xerophytic shrub (salix psammophila) in northern China: implication for beneficial branch architecture to produce stemflow, J. Hydrol., 539, 577-588, 2016.

Yue X., Cui J., Zhang T., Wang S., Lian J., Wang X., Yun J.: Characteristics of rainfall interception and redistribution for Salix gordejevii in Horqin Sandy Land, Northeast China, Acta Prataculturae Sinica, 22(6), 46-52, 2013 (in Chinese with English abstract).

Zhang G., Zeng G. M., Jiang Y. M., Huang G. H., Li J. B., Yao J. M., Tan W., Xiang R., Zhang X. L.: Modelling and measurement of two-layer-canopy interception losses in a subtropical evergreen forest of central-south China, Hydrol. Earth Syst. Sc., 10(1), 65-77, 2006.

Zhang S. Y.: Energy partitioning and evapotranspiration over the typical ecosystems in the Qinghai Lake watershed, Beijing Normal University, 2014 (in Chinese with English abstract).

Zhang S., Li X., Li L., Huang Y., Zhao G., Chen H.: The measurement and modelling of stemflow in an alpine myricaria squamosa community, Hydrol. Process., 29(6), 889-899, 2015a.

Zhang S., Li X., Zhao G., Huang Y.: Surface energy fluxes and controls of evapotranspiration in three alpine ecosystems of Qinghai lake watershed, ne Qinghai-Tibet plateau, Ecohydrology, 9(2), 267-279, $2016 \mathrm{a}$.

Zhang Y., Wang X., Hu R., Pan Y., Paradeloc M.: Rainfall partitioning into throughfall, stemflow and interception loss by two xerophytic shrubs within a rain-fed re-vegetated desert ecosystem, northwestern China, J. Hydrol., 527, 1084-1095, 2015 b.

25 Zhang Z., Zhao Y., Li X., Huang L., Tan H.: Gross rainfall amount and maximum rainfall intensity in 60-minute influence on interception loss of shrubs: a 10-year observation in the Tengger desert, Sci. Rep.-Uk, 6, 26030, 2016 b. 
Hydrol. Earth Syst. Sci. Discuss., doi:10.5194/hess-2016-589, 2016 Manuscript under review for journal Hydrol. Earth Syst. Sci.

Published: 8 December 2016

(c) Author(s) 2016. CC-BY 3.0 License.

\section{(c) (1)}

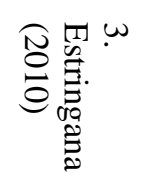

$$
\begin{aligned}
& \text { 욜. }
\end{aligned}
$$

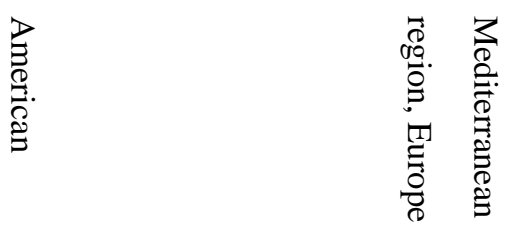

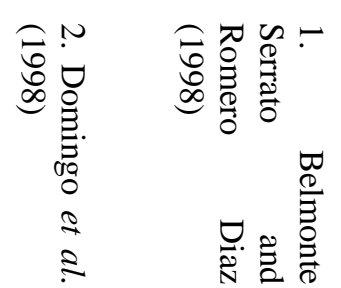

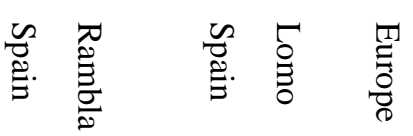

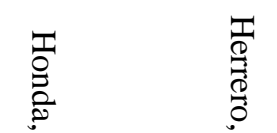

$$
\begin{aligned}
& \text { \& } 8
\end{aligned}
$$

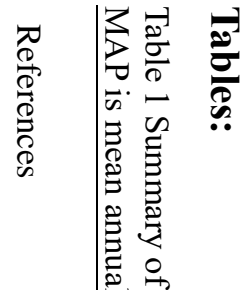

$$
\begin{aligned}
& \frac{z}{s}
\end{aligned}
$$

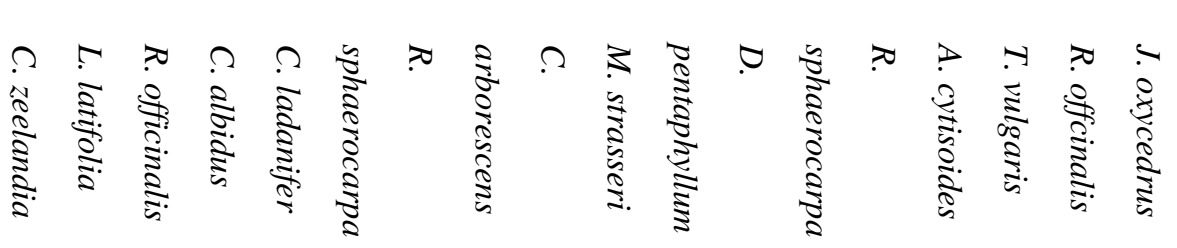

$$
\begin{aligned}
& \stackrel{\sim}{+}
\end{aligned}
$$

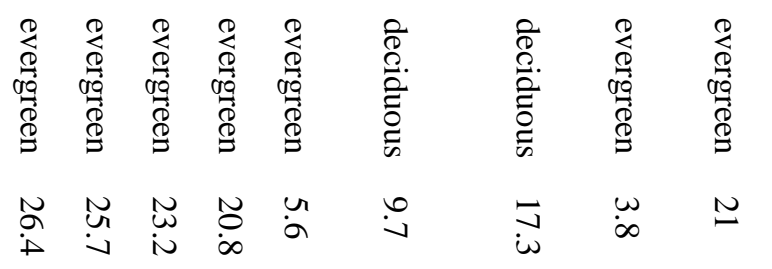

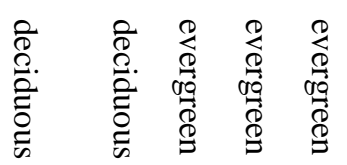

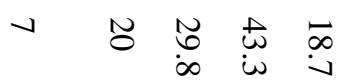

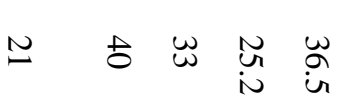

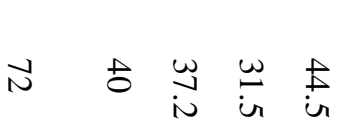

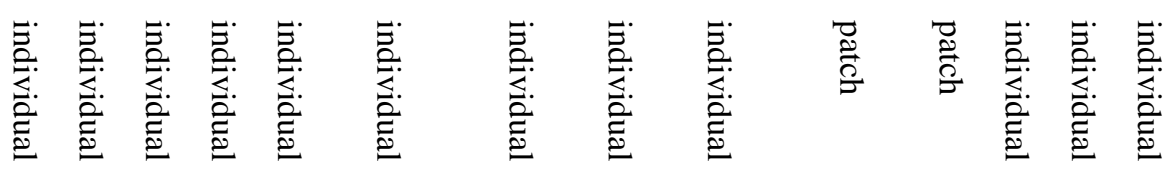
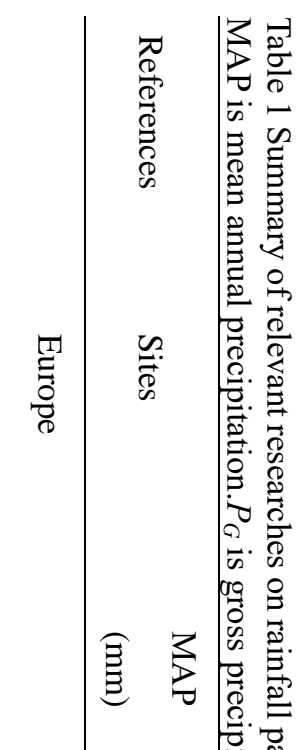
Hydrol. Earth Syst. Sci. Discuss., doi:10.5194/hess-2016-589, 2016 Manuscript under review for journal Hydrol. Earth Syst. Sci.

Published: 8 December 2016

(c) Author(s) 2016. CC-BY 3.0 License.
Hydrology and

Earth System

Sciences

Discussions

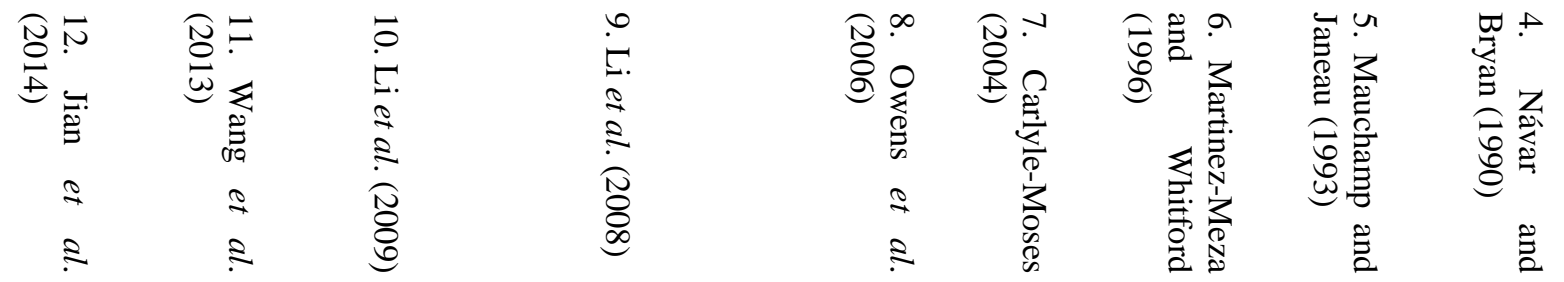

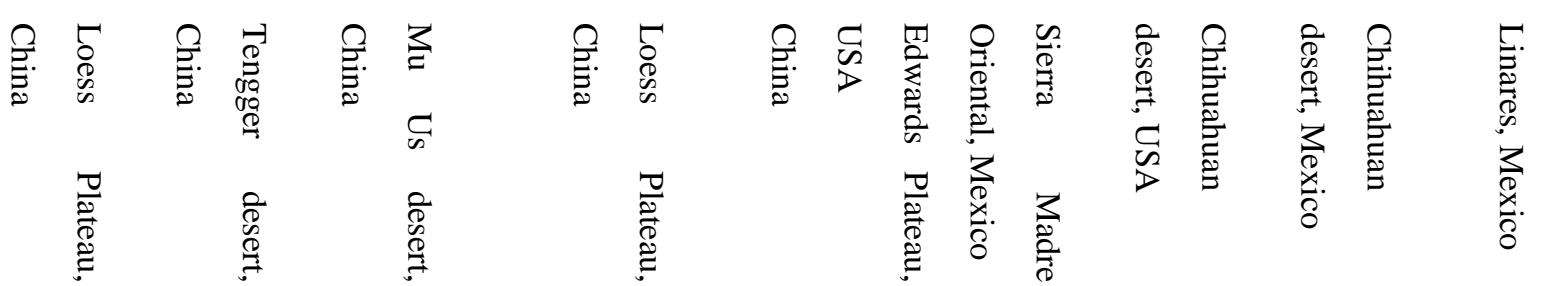

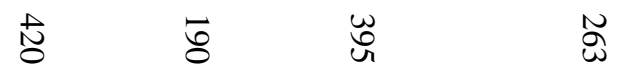

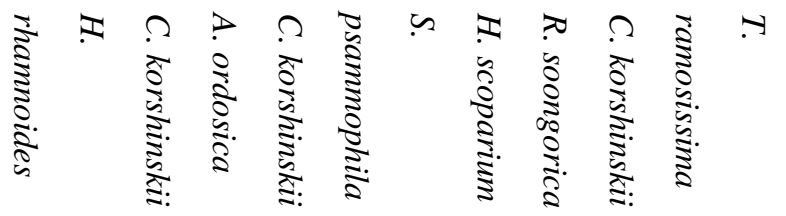

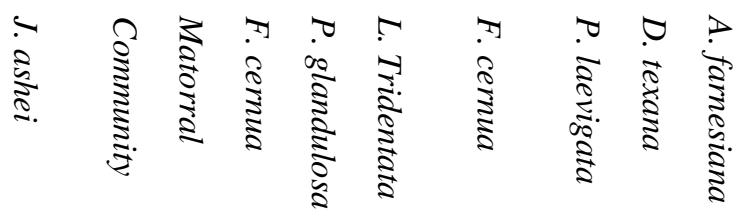

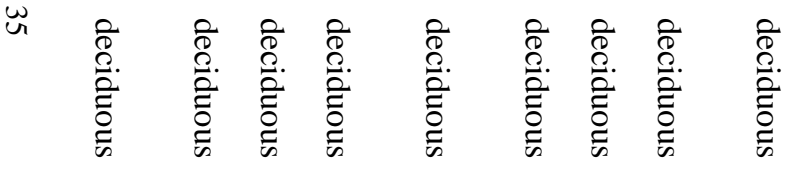

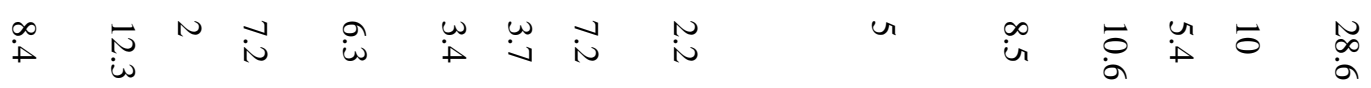

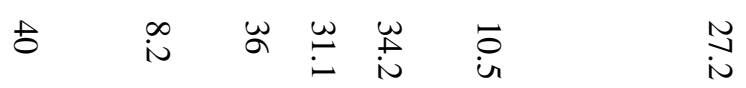

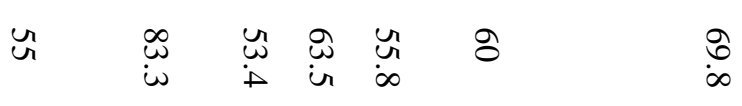

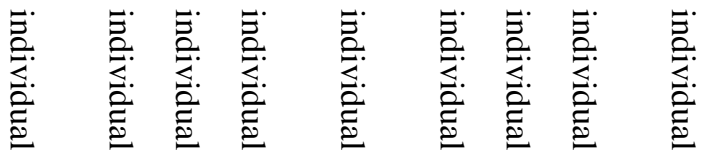

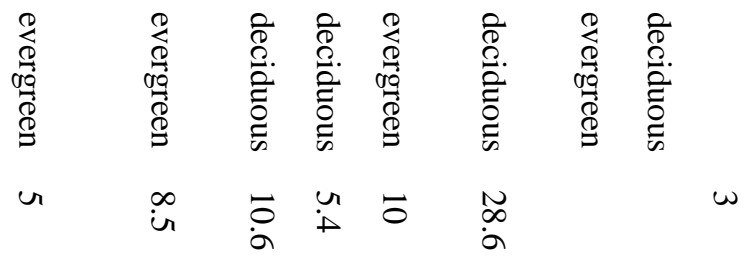

$$
\begin{aligned}
& \begin{array}{lllllll}
\stackrel{n}{\hat{0}} & \stackrel{n}{\hat{0}} & 1 & 1 & 1 & 1 & \text { 营 } \\
& & & & & &
\end{array}
\end{aligned}
$$


Hydrol. Earth Syst. Sci. Discuss., doi:10.5194/hess-2016-589, 2016 Manuscript under review for journal Hydrol. Earth Syst. Sci.

Published: 8 December 2016

(c) Author(s) 2016. CC-BY 3.0 License.
Hydrology and

Earth System

Sciences

Discussions

\section{(c) (1)}

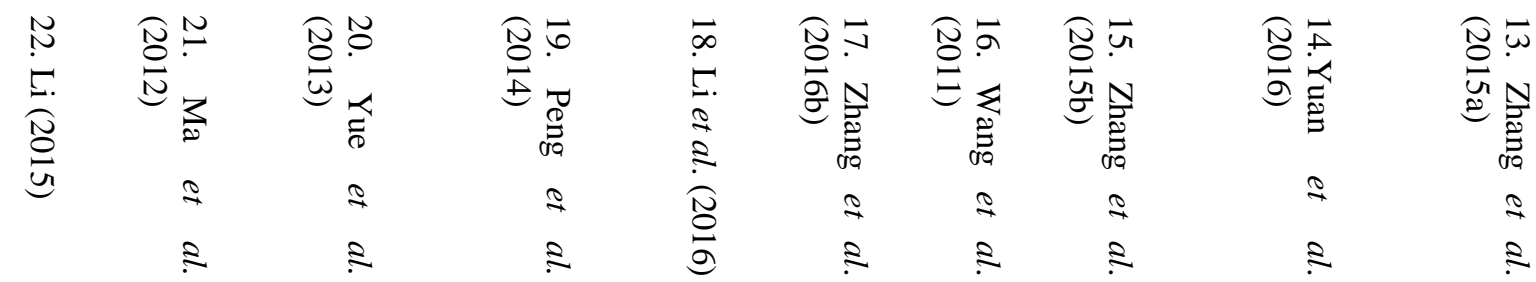

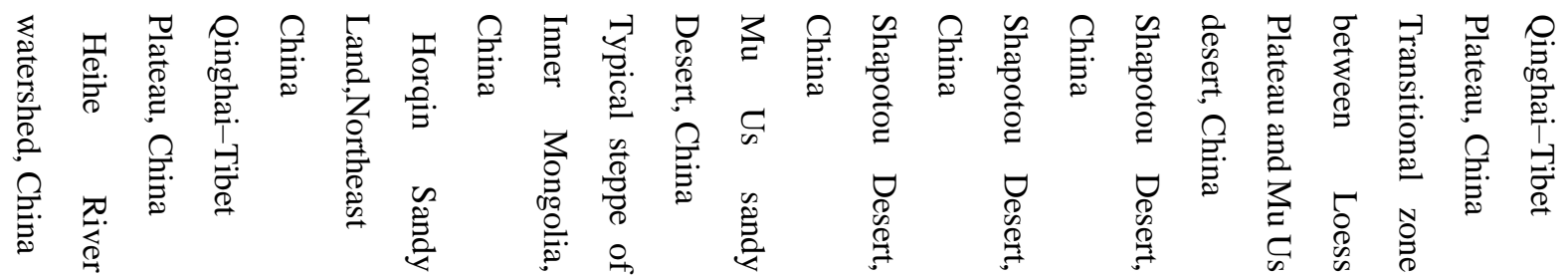

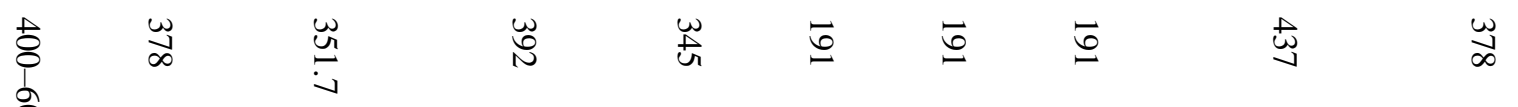

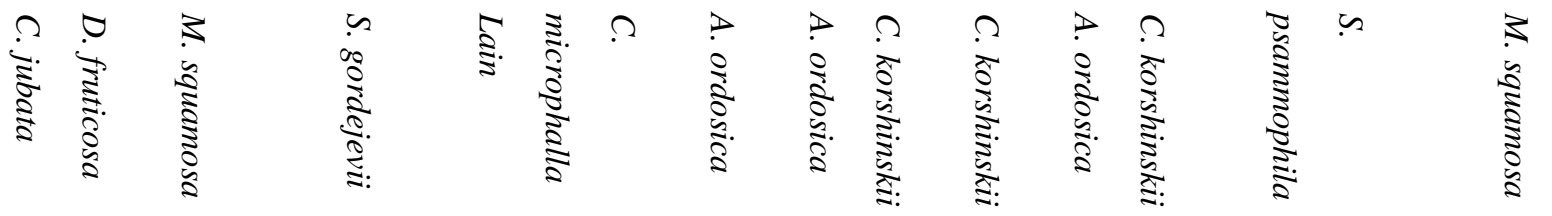

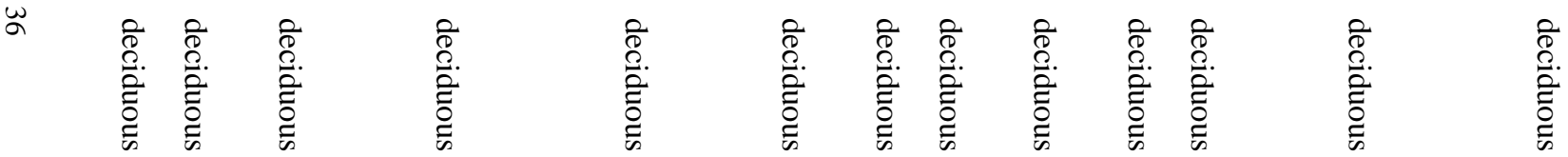

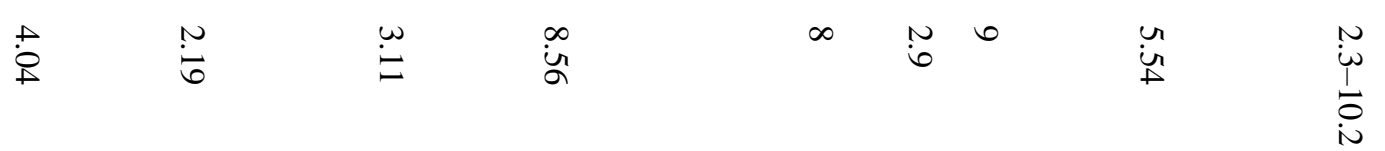

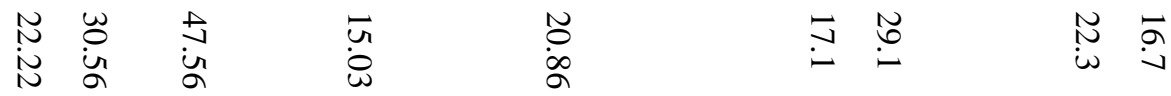

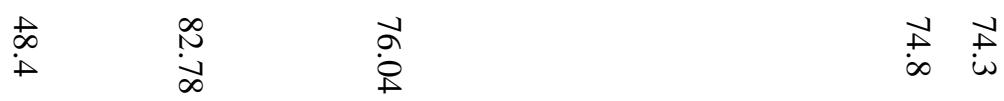

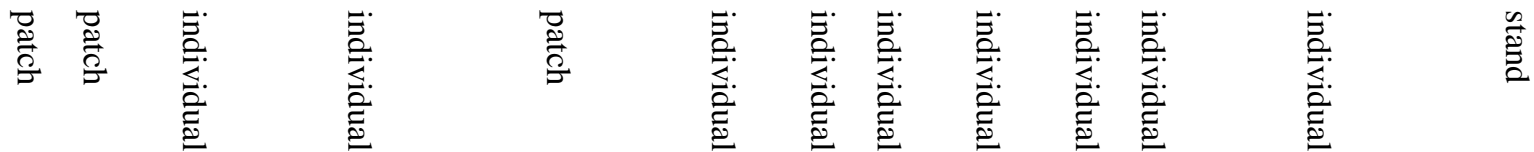


Hydrol. Earth Syst. Sci. Discuss., doi:10.5194/hess-2016-589, 2016

Manuscript under review for journal Hydrol. Earth Syst. Sci.

Published: 8 December 2016

(c) Author(s) 2016. CC-BY 3.0 License.

\section{(c) (1)}

Hydrology and Earth System Sciences

Discussions

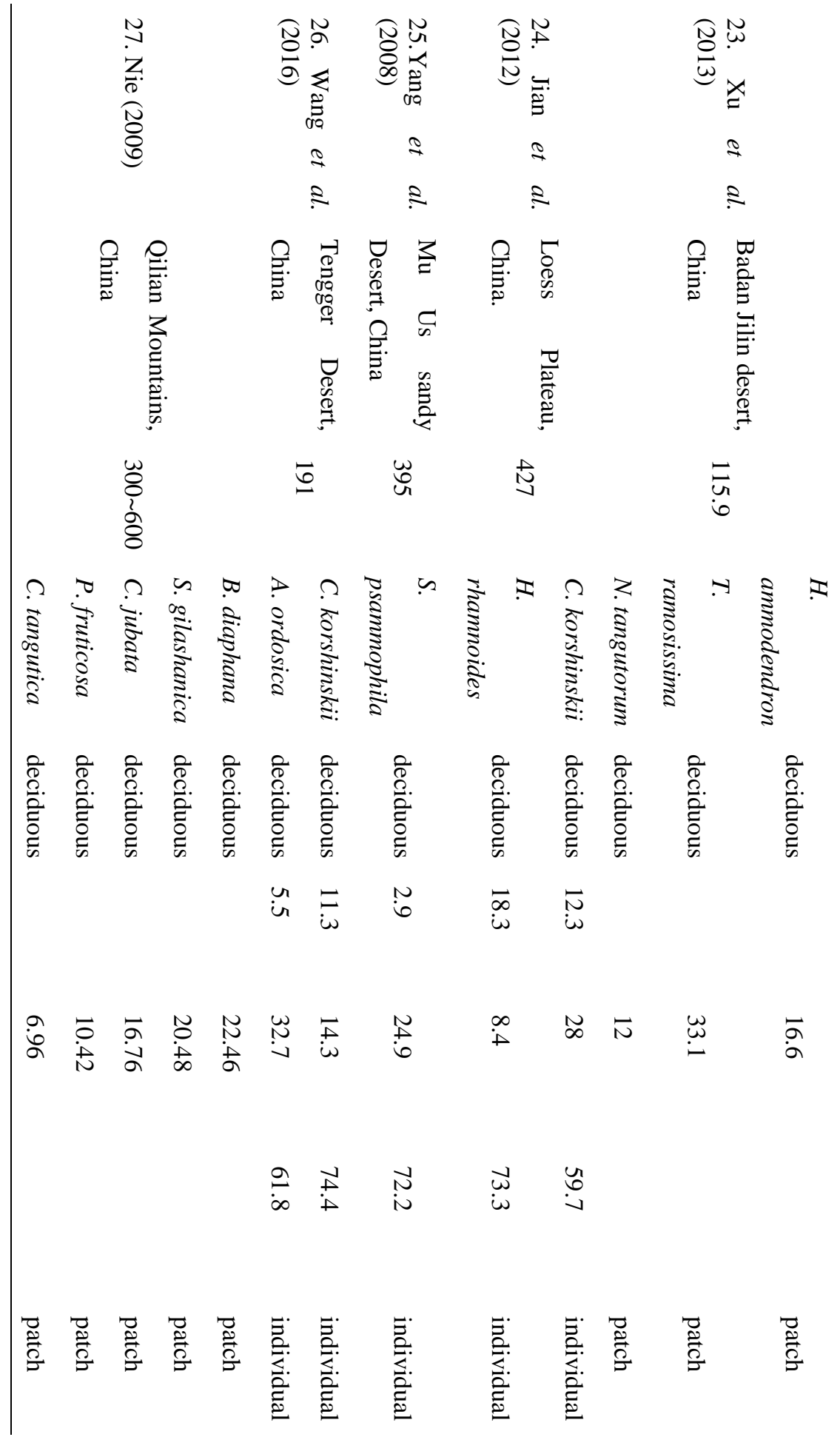


Hydrol. Earth Syst. Sci. Discuss., doi:10.5194/hess-2016-589, 2016 Manuscript under review for journal Hydrol. Earth Syst. Sci.

Published: 8 December 2016

(c) Author(s) 2016. CC-BY 3.0 License.

\section{(c) (i)}

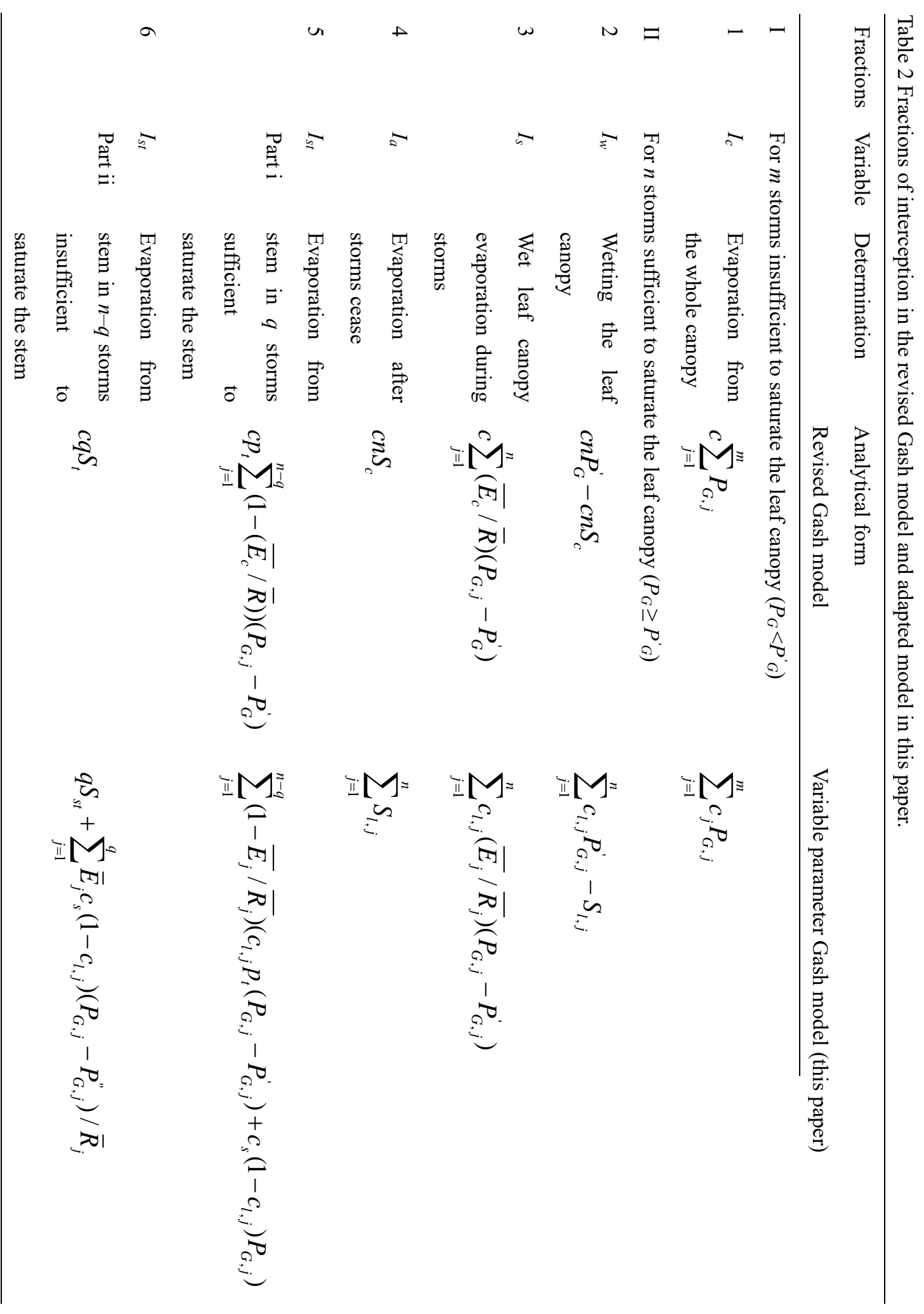


Hydrol. Earth Syst. Sci. Discuss., doi:10.5194/hess-2016-589, 2016

Manuscript under review for journal Hydrol. Earth Syst. Sci.

Published: 8 December 2016

(c) Author(s) 2016. CC-BY 3.0 License.

(c) (1)

Table 3 Observed rainfall partitioning pattern in the P. fruticosa shrub patches

\begin{tabular}{|c|c|c|c|c|c|c|c|}
\hline \multirow{2}{*}{ Record date } & \multicolumn{2}{|c|}{ Rainfall events } & \multicolumn{2}{|c|}{ Rainfall } & \multirow{2}{*}{ Throughfall } & \multirow{2}{*}{ Stemflow } & \multirow{2}{*}{ Interception } \\
\hline & Total & $q$ & Gross & $q$ events & & & \\
\hline & & & $\mathrm{mm}$ & $\mathrm{mm}$ & $\mathrm{mm}$ & $\mathrm{mm}$ & $\mathrm{mm}$ \\
\hline 2012/6/11 & 7 & 3 & 22.8 & 20.20 & 6.35 & 7.83 & 8.6 \\
\hline $2012 / 6 / 20$ & 7 & 6 & 40.8 & 40.60 & 15.45 & 12.37 & 13.0 \\
\hline $2012 / 6 / 29$ & 7 & 6 & 67.4 & 67.20 & 21.80 & 28.80 & 16.8 \\
\hline 2012/7/17 & \multicolumn{7}{|c|}{ Data missing } \\
\hline $2012 / 7 / 31$ & 9 & 6 & 70.8 & 68.40 & 19.50 & 30.93 & 20.4 \\
\hline $2012 / 8 / 22$ & 15 & 7 & 206.8 & 204.80 & 60.04 & 121.46 & 25.3 \\
\hline $2012 / 9 / 2$ & 5 & 3 & 42.2 & 41.80 & 9.50 & 20.41 & 12.3 \\
\hline $2012 / 9 / 11$ & 5 & 2 & 34.0 & 33.40 & 9.20 & 17.20 & 7.6 \\
\hline Total & 55.0 & 33.0 & 484.8 & 476.4 & 141.9 & 239.0 & 103.9 \\
\hline
\end{tabular}


Hydrol. Earth Syst. Sci. Discuss., doi:10.5194/hess-2016-589, 2016

Manuscript under review for journal Hydrol. Earth Syst. Sci.

Published: 8 December 2016

(c) Author(s) 2016. CC-BY 3.0 License.

Table 4 Estimated rainfall partitioning pattern in the P. fruticosa shrub patches using the revised Gash model. EV: Estimated values, EE: Estimated error

\begin{tabular}{lllllll}
\hline & Throughfall & \multicolumn{3}{c}{ Stemflow } & \multicolumn{2}{l}{ Interception } \\
\cline { 2 - 7 } Record Date & EV & EE & EV & EE & EV & EE \\
& $\mathrm{mm}$ & $\%$ & $\mathrm{~mm}$ & $\%$ & $\mathrm{~mm}$ & $\%$ \\
\hline $2012 / 6 / 11$ & 4.95 & -22.12 & 8.41 & 7.39 & 9.4 & 9.6 \\
$2012 / 6 / 20$ & 9.09 & -41.2 & 16.19 & 30.86 & 15.5 & 19.6 \\
$2012 / 6 / 29$ & 18.26 & -16.22 & 35.69 & 23.91 & 13.5 & -20 \\
$2012 / 7 / 17$ & Data missing & & & & & \\
$2012 / 7 / 31$ & 16.47 & -15.57 & 31.59 & 2.13 & 22.7 & 11.7 \\
$2012 / 8 / 22$ & 57.08 & -4.94 & 117.44 & -3.31 & 32.3 & 27.6 \\
$2012 / 9 / 2$ & 10.12 & 6.5 & 19.25 & -5.69 & 12.8 & 4.4 \\
$2012 / 9 / 11$ & 8.77 & -4.67 & 17.63 & 2.46 & 7.6 & 0.1 \\
Total & 124.7 & -12.07 & 246.2 & 3.01 & 113.9 & 9.6 \\
\hline
\end{tabular}


Hydrol. Earth Syst. Sci. Discuss., doi:10.5194/hess-2016-589, 2016

Manuscript under review for journal Hydrol. Earth Syst. Sci.

Published: 8 December 2016

(c) Author(s) 2016. CC-BY 3.0 License.

(c) (i)

Discussions

Table 5 Estimated rainfall partitioning pattern in the $P$. fruticosa shrub patches using the variable parameters Gash model

\begin{tabular}{lllllll}
\hline & \multicolumn{2}{l}{ Throughfall } & \multicolumn{2}{l}{ Stemflow } & \multicolumn{2}{l}{ Interception } \\
\cline { 2 - 7 } Record Date & EV & EE & EV & EE & EV & EE \\
& $\mathrm{mm}$ & $\%$ & $\mathrm{~mm}$ & $\%$ & $\mathrm{~mm}$ & $\%$ \\
\hline $2012 / 6 / 11$ & 7.0 & 10.6 & 8.6 & 9.9 & 7.2 & -16.8 \\
$2012 / 6 / 20$ & 12.1 & -21.8 & 16.1 & 30.4 & 12.6 & -2.9 \\
$2012 / 6 / 29$ & 22.6 & 3.7 & 33.1 & 14.8 & 11.7 & -30.3 \\
$2012 / 7 / 17$ & Data missing & & & & \\
$2012 / 7 / 31$ & 18.0 & -7.6 & 29.5 & -4.6 & 23.3 & 14.3 \\
$2012 / 8 / 22$ & 58.3 & -2.8 & 115.2 & -5.2 & 33.3 & 31.6 \\
$2012 / 9 / 2$ & 11.7 & 23.6 & 17.8 & -12.6 & 12.6 & 2.6 \\
$2012 / 9 / 11$ & 10.4 & 12.6 & 16.7 & -2.7 & 6.9 & -9.1 \\
Total & 140.2 & -1.2 & 237.1 & -0.8 & 107.5 & 3.5 \\
\hline
\end{tabular}


Hydrol. Earth Syst. Sci. Discuss., doi:10.5194/hess-2016-589, 2016

Manuscript under review for journal Hydrol. Earth Syst. Sci.

Published: 8 December 2016

(c) Author(s) 2016. CC-BY 3.0 License.

Table 6 Rainfall partitioning predicted by the revised Gash model and the new Gash model. RG: value predicted from the revised Gash model, VG: value predicted from the variable parameters Gash model.

\begin{tabular}{llllllll}
\hline Items & & \multicolumn{2}{c}{ Amount } & \multicolumn{3}{c}{ Percentage of gross precipitation } & \multicolumn{2}{c}{ Percentage of total Interception } \\
& & RG & VG & RG & VG & RG & VG \\
& & $\mathrm{mm}$ & $\mathrm{mm}$ & $\%$ & $\%$ & $\%$ & $\%$ \\
\hline Throughfall & & 124.7 & 140.2 & 25.7 & 28.9 & & \\
Stemflow & & 246.2 & 237.1 & 50.8 & 48.9 & & 100 \\
Interception & Total & 113.9 & 107.5 & 23.5 & 22.2 & 100 & 6.4 \\
& $I_{c}$ & 7.4 & 6.9 & 1.5 & 1.4 & 6.5 & 2.7 \\
& $I_{w}$ & 2.8 & 2.9 & 0.6 & 0.6 & 2.5 & 42.6 \\
& $I_{s}$ & 60.8 & 45.8 & 12.5 & 9.5 & 53.4 & 20.4 \\
& $I_{a}$ & 22.9 & 21.9 & 4.7 & 4.5 & 20.1 & 28.0 \\
\hline
\end{tabular}


Hydrol. Earth Syst. Sci. Discuss., doi:10.5194/hess-2016-589, 2016

Manuscript under review for journal Hydrol. Earth Syst. Sci.

Published: 8 December 2016

(c) Author(s) 2016. CC-BY 3.0 License.

Table 7 Summary of components of simulated interception using revised Gash model

\begin{tabular}{|c|c|c|c|c|c|c|c|c|c|}
\hline Reference & Sites & $\underset{a}{\text { MAP }}$ & Species & $\begin{array}{l}I \\
\mathrm{~mm}\end{array}$ & $\begin{array}{l}I_{c} \\
\%\end{array}$ & $\begin{array}{l}I_{w} \\
\%\end{array}$ & $\begin{array}{l}I_{s} \\
\%\end{array}$ & $\begin{array}{l}I_{a} \\
\%\end{array}$ & $\begin{array}{l}I_{t} \\
\%\end{array}$ \\
\hline 1. Dykes (1997) & $\begin{array}{l}\text { Temburong } \\
\text { District, Brunei }\end{array}$ & 4582 & $\begin{array}{l}\text { Mixed Dipterocarp } \\
\text { rainforest }\end{array}$ & 68.4 & 4.7 & 1.9 & 63.0 & 27.8 & 2.6 \\
\hline $\begin{array}{l}\text { 2. Carlyle-Moses } \\
\text { and Price (1999) }\end{array}$ & Ontario, Canada & 785 & $\begin{array}{l}\text { Q. ruba, A. } \\
\text { saccharum, } F . \\
\text { grandifolia }\end{array}$ & 41.3 & 4.8 & 2.2 & 27.1 & 59.8 & 5.8 \\
\hline $\begin{array}{l}\text { 3. Aboal et al. } \\
\text { (1999) }\end{array}$ & Tenerife, Spain & 733 & laurel forest & 166.0 & 12.0 & 1.0 & 9.0 & 74.0 & 3.0 \\
\hline \multirow{2}{*}{$\begin{array}{l}\text { 4. van Dijk and } \\
\text { Bruijnzeel } \\
\text { (2001b) }\end{array}$} & \multirow{2}{*}{ Java, Indonesia } & \multirow{2}{*}{2600} & \multirow{2}{*}{$\begin{array}{l}\text { M. esculenta Crantz; } Z \text {. } \\
\text { mays L.; O. sativa L. }\end{array}$} & 311.5 & 0.0 & 4.6 & 91.2 & 4.0 & 0.2 \\
\hline & & & & 132.8 & 0.1 & 8.1 & 84.0 & 7.6 & 0.3 \\
\hline \multirow{3}{*}{$\begin{array}{l}\text { 5. Link et al. } \\
\text { (2004) }\end{array}$} & \multirow{3}{*}{$\begin{array}{l}\text { Washington, } \\
\text { USA }\end{array}$} & \multirow{3}{*}{2467} & \multirow{3}{*}{$\begin{array}{l}\text { P. menzesii, } T \text {. } \\
\text { heterophylla, and } T \text {. } \\
\text { plicata }\end{array}$} & 126.7 & 29.0 & 4.0 & 30.0 & 37.0 & - \\
\hline & & & & 106.9 & 35.0 & 5.0 & 17.0 & 44.0 & - \\
\hline & & & & 136.9 & 40.0 & 5.0 & 11.0 & 44.0 & - \\
\hline $\begin{array}{l}\text { 6. Deguchi et al. } \\
\text { (2006) }\end{array}$ & $\begin{array}{l}\text { Aichi Prefecture, } \\
\text { Japan }\end{array}$ & $\begin{array}{l}1498 \\
.4\end{array}$ & $\begin{array}{l}Q . \text { serrata and } C \text {. } \\
\text { barbinervis, etc. }\end{array}$ & $\begin{array}{l}699.5 \\
2\end{array}$ & 4.8 & 3.2 & 70.8 & 29.3 & - \\
\hline $\begin{array}{l}\text { 7. Zhang et al. } \\
\text { (2006) }\end{array}$ & $\begin{array}{l}\text { Hunan province, } \\
\text { China }\end{array}$ & $\begin{array}{l}1200 \\
- \\
1500\end{array}$ & $\begin{array}{l}\text { C. japonica, } N . \text { indicum, } \\
\text { E. japonicas, } T \text {. } \\
\text { gymnanthera }\end{array}$ & 118.5 & 3.3 & 12.9 & 32.0 & 48.1 & 3.7 \\
\hline \multirow{2}{*}{$\begin{array}{l}\text { 8. Murakami } \\
\text { (2007) }\end{array}$} & \multirow{2}{*}{ Japan } & \multirow{2}{*}{$\begin{array}{l}1467 \\
.7\end{array}$} & C. obtusa, 1999 & 320.1 & 2.0 & 1.1 & 80.1 & 8.9 & 7.9 \\
\hline & & & C. obtusa, 2000 & 256.4 & 2.4 & 1.3 & 73.9 & 11.9 & 10.4 \\
\hline \multirow{5}{*}{$\begin{array}{l}\text { 9. Wallace and } \\
\text { Mcjannet (2008) }\end{array}$} & \multirow{5}{*}{$\begin{array}{l}\text { Queensland, } \\
\text { Australian }\end{array}$} & \multirow{5}{*}{-} & Oliver Creek & $\begin{array}{l}1085 . \\
0\end{array}$ & 14.7 & 2.4 & 21.5 & 58.9 & 2.6 \\
\hline & & & Hutchinson Creek & 900.0 & 13.8 & 2.8 & 34.6 & 45.8 & 3.1 \\
\hline & & & Mount Lewis & $\begin{array}{l}1193 . \\
0\end{array}$ & 21.3 & 3.8 & 25.6 & 47.3 & 2.0 \\
\hline & & & Mount Lewis & 509.0 & 22.6 & 4.1 & 25.9 & 44.8 & 2.6 \\
\hline & & & Upper Barron & 428.0 & 15.4 & 4.0 & 46.0 & 32.7 & 1.9 \\
\hline \multirow{2}{*}{$\begin{array}{l}\text { 10. Limousin et } \\
\text { al. }(2008)\end{array}$} & \multirow{2}{*}{$\begin{array}{l}\text { Montpellier, } \\
\text { France }\end{array}$} & \multirow{2}{*}{908} & Q. ilex, control plot & 396.5 & 31.2 & 2.8 & 17.8 & 38.1 & 10.1 \\
\hline & & & Q. ilex, thinned plot & 260.1 & 31.5 & 4.9 & 17.9 & 35.8 & 9.9 \\
\hline \multirow[t]{2}{*}{$\begin{array}{l}\text { 11. Shi et al. } \\
\text { (2010) }\end{array}$} & \multirow[t]{2}{*}{$\begin{array}{l}\text { Liupan } \\
\text { Mountains, } \\
\text { China }\end{array}$} & $\begin{array}{l}591 . \\
6\end{array}$ & P. armandii & 72.5 & 1.7 & 2.7 & 39.5 & 55.2 & 0.9 \\
\hline & & 1405 & B. aemula R.Br. & 158.6 & 0.0 & 2.5 & 77.3 & 16.6 & 3.6 \\
\hline
\end{tabular}


Hydrol. Earth Syst. Sci. Discuss., doi:10.5194/hess-2016-589, 2016

Manuscript under review for journal Hydrol. Earth Syst. Sci.

Published: 8 December 2016

(c) Author(s) 2016. CC-BY 3.0 License.

(c) (i)

12. Fan et al. Bribie Island,

(2014)

Australia

13. Sun et al. Mt. Karasawa,

(2015)
Japan
P. elliottii Engelm, $P$.

$\begin{array}{lllllll}\text { caribaea } \text { Morelet var. } & 211.6 & 1.4 & 1.9 & 51.6 & 34.8 & 7.4\end{array}$

hondurensis

1265

$\begin{array}{lllllll}\text { C. obtusa, pre-thinning } \quad 209.3 & 4.4 & 2.5 & 62.9 & 26.8 & 3.4\end{array}$ \begin{tabular}{c} 
Hydrology and 을 \\
Earth System \\
Sciences \\
\hline Discussions
\end{tabular}

$\begin{array}{lllllll}\text { C. obtusa, post-thinning } \quad 104.4 & 2.3 & 2.8 & 45.4 & 40.3 & 9.2\end{array}$ 
Hydrol. Earth Syst. Sci. Discuss., doi:10.5194/hess-2016-589, 2016

\section{(c) (1)}

\section{Figures:}
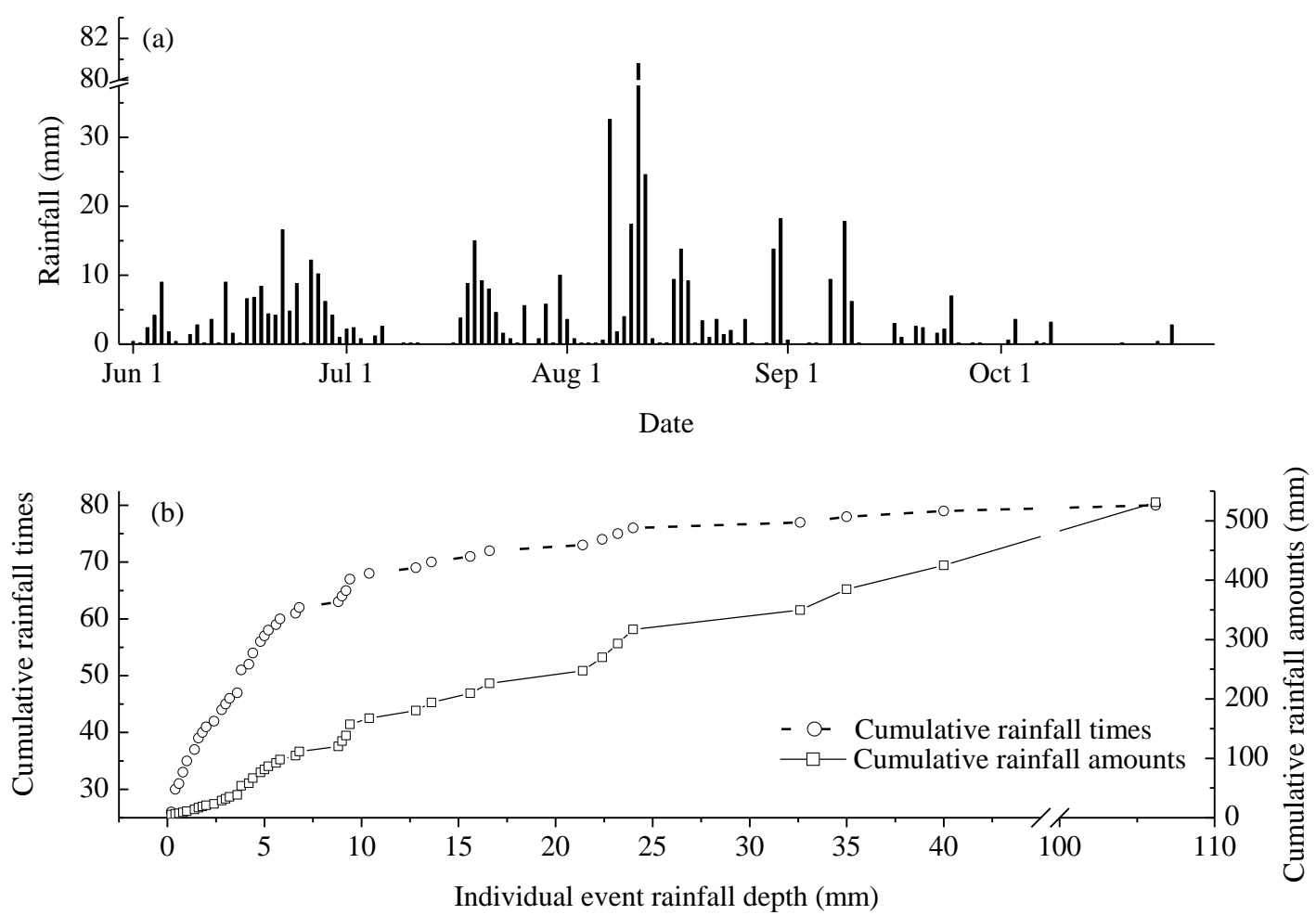

Figure 1 (a) daily rainfall depth during June and October, 2012; (b) cumulative rainfall events and amount of different individual event rainfall depth. 
Hydrol. Earth Syst. Sci. Discuss., doi:10.5194/hess-2016-589, 2016

Manuscript under review for journal Hydrol. Earth Syst. Sci.

Published: 8 December 2016

(c) Author(s) 2016. CC-BY 3.0 License.

\section{(c) (1)}
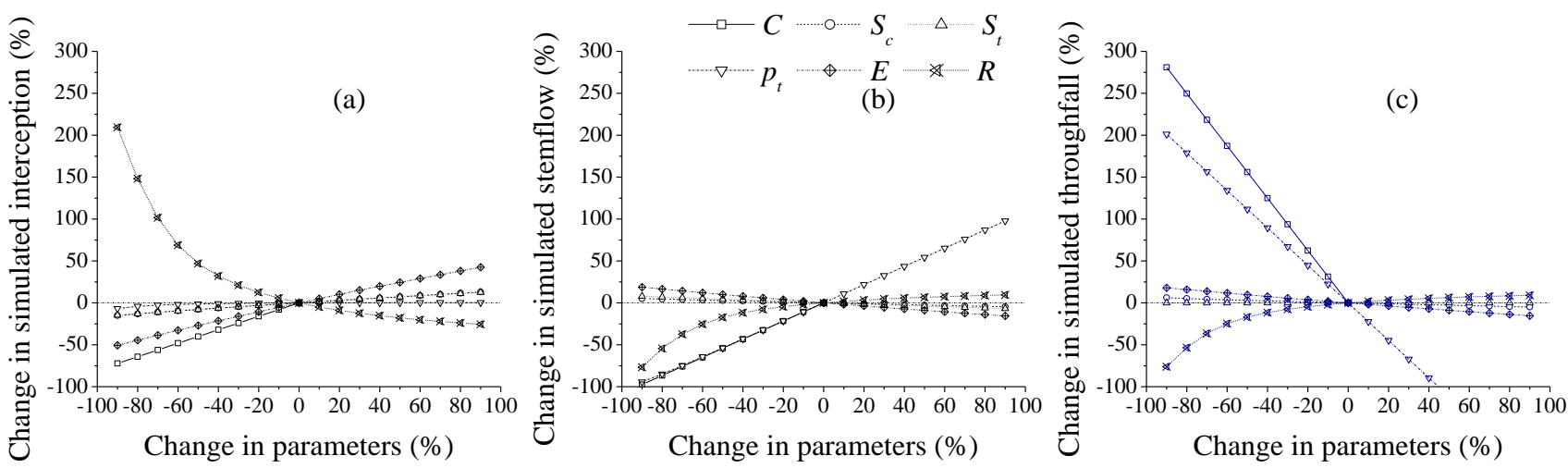

Figure 2 Sensitivity analysis of the parameters of the revised Gash model

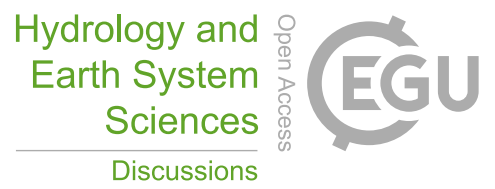


Hydrol. Earth Syst. Sci. Discuss., doi:10.5194/hess-2016-589, 2016

Manuscript under review for journal Hydrol. Earth Syst. Sci.

Published: 8 December 2016

(c) Author(s) 2016. CC-BY 3.0 License.

(c) (i)
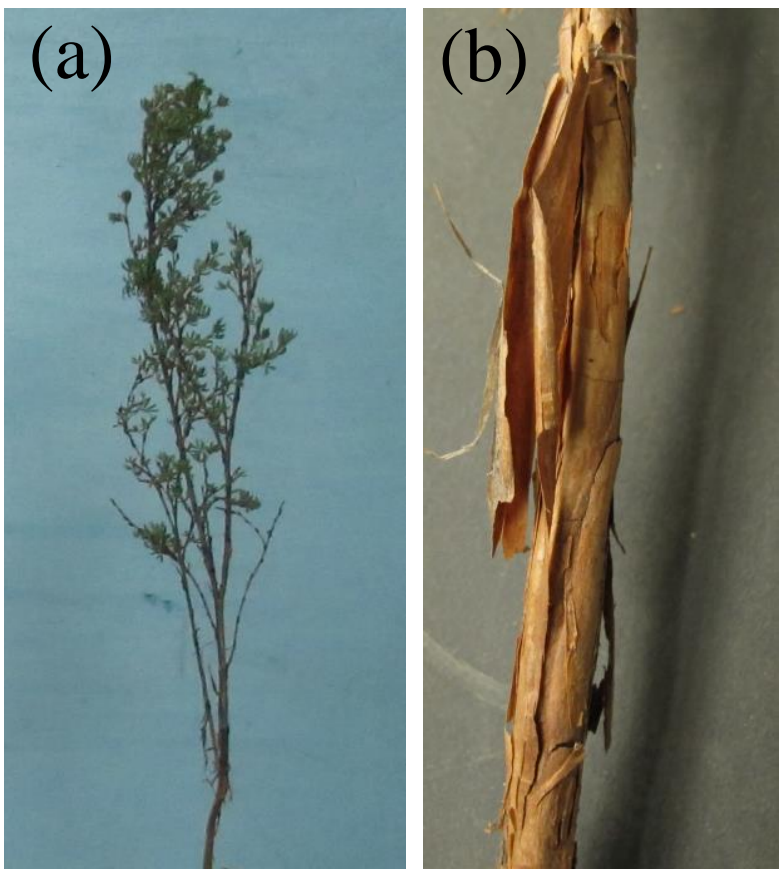

Figure 3 Photos of (a) a typical P. fruticosa branch and (b) its bark

\section{Hydrology and Earth System Sciences \\ Discussions

